DR. VINCENT E.J. JASSEY (Orcid ID : 0000-0002-1450-2437)

DR. BJORN ROBROEK (Orcid ID : 0000-0002-6714-0652)

Article type : Primary Research Articles

Paper type: Primary Research Article

\title{
Tipping point effect in plant-fungal interactions under severe drought causes abrupt rise in peatland ecosystem respiration
}

Vincent E.J. Jassey1,2,3*, Monika K. Reczuga4, Małgorzata Zielińska4, Sandra Słowińska5, Bjorn J.M. Robroek $^{6}$, Pierre Mariotte ${ }^{2,3}$, Christophe V.W. Seppey,8, Enrique Lara9 ${ }^{9}$ Jan Barabach4, Michal Słowiński10,11, Luca Bragazza ${ }^{2,3,12}$, Bogdan H. Chojnicki13, Mariusz Lamentowicz ${ }^{4}$, Edward A.D. Mitchell7, Alexandre Buttler2,3

${ }^{1}$ Université de Toulouse, INP, UPS, CNRS, Laboratoire d'Ecologie Fonctionnelle et Environnement, 118 Route de Narbonne, 31062 Toulouse Cedex, France

2 École Polytechnique Fédérale de Lausanne (EPFL), Ecological Systems Laboratory (ECOS), CH1015 Lausanne, Switzerland.

${ }^{3}$ WSL - Swiss Federal Institute for Forest, Snow and Landscape Research, Site Lausanne, CH1015 Lausanne, Switzerland.

${ }^{4}$ Laboratory of Wetland Ecology and Monitoring \& Department of Biogeography and Palaeoecology, Adam Mickiewicz University in Poznań, Krygowskiego 10, 61-680 Poznań, Poland

5 Department of Geoecology and Climatology, Institute of Geography and Spatial Organization, Polish Academy of Sciences, Twarda 51/55, 00-818 Warsaw, Poland

${ }^{6}$ Biological Sciences, University of Southampton, Southampton, S017 1BJ, United Kingdom 7 University of Neuchâtel, Laboratory of Soil Biodiversity, CH-2000 Neuchâtel, Switzerland 8 University of Tromsø, Arctic and Marine Biology Department, 9037 Tromsø, Norway

This article has been accepted for publication and undergone full peer review but has not been through the copyediting, typesetting, pagination and proofreading process, which may lead to differences between this version and the Version of Record. Please cite this article as doi: $10.1111 /$ gcb.13928

This article is protected by copyright. All rights reserved. 
${ }^{9}$ Real Jardín Botánico, CSIC, 28014 Madrid, Spain

10 Department of Environmental Resources and Geohazards, Institute of Geography and Spatial Organization, Polish Academy of Sciences, Twarda51/55,00-818 Warszawa, Poland

11 GFZ German Research Centre for Geosciences, Section5.2-Climate Dynamics and Landscape Evolution, Telegrafenberg, D-14473 Potsdam, Germany

12 Department of Life Science and Biotechnologies, University of Ferrara, Corso Ercole I d'Este 32, I-44121 Ferrara, Italy

13 Poznan University of Life Sciences, Meteorology Department, ul. Piątkowska 94, 60-649

Poznań, Poland

Running headline: Tipping point in peatland response to drought

*Corresponding author; phone: +33 (0) 561558 923;

E-mail address: vincent.jassey@univ-tlse3.fr

Keywords: biodiversity-ecosystem functioning; ecosystem shifts; fungal diversity; hydrolases; oxidases; plant-soil feedbacks; moving window SEM; threshold

\section{Abstract}

Ecosystems are increasingly prone to climate extremes, such as drought, with long lasting effects on both plant and soil communities and, subsequently, on carbon (C) cycling. However, recent studies underlined the strong variability in ecosystem's response to droughts, raising the issue of non-linear responses in plant and soil communities. The conundrum is what causes ecosystems to shift in response to drought. Here, we investigated the response of plant and soil fungi to drought of different intensities using a water table gradient in peatlands - a major C sink ecosystem. Using moving window structural equation models, we show that substantial changes in ecosystem respiration, plant and soil fungal communities occurred when the water level fell below a tipping point of $-24 \mathrm{~cm}$. As a corollary, ecosystem respiration was the greatest when graminoids and saprotrophic fungi became prevalent as a response to the extreme

This article is protected by copyright. All rights reserved. 
drought. Graminoids indirectly influenced fungal functional composition and soil enzyme activities through their direct effect on dissolved organic matter quality, while saprotrophic fungi directly influenced soil enzyme activities. In turn, increasing enzyme activities promoted ecosystem respiration. We show that functional transitions in ecosystem respiration critically depends on the degree of response of graminoids and saprotrophic fungi to drought. Our results represent a major advance in understanding the non-linear nature of ecosystem properties to drought and pave the way towards a truly mechanistic understanding of the effects of drought on ecosystem processes.

\section{Introduction}

Climate change is expected to increase the frequency and intensity of droughts (Dai, 2013; Berg et al., 2016). Such alterations in the environmental conditions can cause dramatic shifts in plant (Felton \& Smith, 2017; Wellstein et al., 2017) and soil communities (de Vries et al., 2012; Barnard et al., 2013; Rousk et al., 2013; Fuchslueger et al., 2016) as well as on associated ecological processes (Fuchslueger et al., 2013; Kaisermann et al., 2015; Hoover \& Rogers, 2016). These shifts can either gradually or suddenly alter ecosystem functions, often with important consequences for the goods and services that ecosystems can provide to humans (Bardgett et al., 2008; Frank et al., 2015). However, the amount and rate of drought-induced ecological changes still remain highly uncertain (Hoover \& Rogers, 2016). While the majority of studies reports significant changes in the strength and/or direction of the relationship between biodiversity and ecosystem functions in response to drought (Fuchslueger et al., 2013; Rousk et al., 2013; Tilman et al., 2014), others showed no shifts (Sistla et al., 2014; Canarini et al., 2016; Hoover \& Rogers, 2016; Domínguez et al., 2017). These contrasting results suggest that climateecosystem relationships are often nonlinear and ecosystem functions sometimes remain close to a critical tipping point - a biophysical threshold where shifts in species diversity and interactions within communities may flip ecosystem functions to an alternative state, involving

This article is protected by copyright. All rights reserved. 
positive feedbacks among species at an unstable equilibrium (Scheffer \& Carpenter, 2003; Briske et al., 2006; van de Pol et al., 2017). The disturbance force ensuring that stress-induced changes in biodiversity effects on ecosystem functions remain close or cross a tipping point is, however, poorly understood (Baert et al., 2016).

In ecosystems subjected to severe droughts, primary productivity typically decreases (Zhao \& Running, 2010) and global soil carbon (C) loss increases (Crowther et al., 2016; Hicks Pries et al., 2017). Shifts in plant and soil biodiversity have emerged as the prominent determinants of such changes in ecosystem processes (van der Putten et al., 2013). However, there is less evidence of the functional identity of plants and/or soil micro-biota (bacteria, fungi, archaea, and protists) driving ecosystem shifts (Bardgett et al., 2013). Also, the evidence that drought affects ecosystem functions because of changes in the strength of interactions between specific plant and soil microbiota is mixed, at best (Loreau, 2001; Fuchslueger et al., 2013). As a result, it is still unclear how compositional changes in plant and soil communities can influence each other and to what extent these changes can drive ecosystems beyond an alternative state.

The independent response of a species to drought across a trophic level (e.g. a plant) can feedback on species from other trophic level (e.g. soil microbes) through cascading effects. While in principle these shifts can lead to ecosystem changes, they do not necessarily have to, as they can have major biological impact without overhauling the essential properties and functions of the ecosystem (van de Pol et al., 2017). Compensatory mechanisms, such as the replacement of sensitive species by stress-tolerant species, may determine the magnitude of ecological changes in response to climate change (Lu et al., 2016). If a sensitive species is replaced by a stress-tolerant species that shares the same functional attributes, specific speciesdriven ecosystem functions should barely change. On the opposite, replacement of sensitive species by a stress-tolerant competitor with different functional attributes should disrupt This article is protected by copyright. All rights reserved. 
exiting species interactions, even create novel interactions, and hence alter ecosystem function (Fox, 2005).

Identifying explicitly the dynamic of plant-soil microbe interactions in response to drought and the amount of changes in plant-microbial feedbacks that pushes ecosystems towards an alternative state is essential for ecosystem management but still remains virtually unexplored. Here, we determine the level of drought that can modify plant-soil microbe interactions in a peatland ecosystem. Northern peatlands play an important role for the global C cycle as they represent a large but vulnerable pool of soil C (Dise, 2009). They store as peat over 500 Pg C mostly preserved by a high water table that limits decomposition (Yu et al., 2011). As such, peatlands are vulnerable to droughts and the interplay between plant and soil microbiota is central to how peatlands will respond to drought given their strong links with C cycle (Ward et al., 2015; Bragazza et al., 2016; Dieleman et al., 2016; Robroek et al., 2016). Any shifts in the direction and/or strength of plant-soil microbe interactions could destabilize the peatland C balance (Kuiper et al., 2014). Likely, a pre-threshold state within soil and/or plant components must exist and necessarily reached before peatland functions shift in response to drought.

In this study, we use data from a unique water level manipulation experiment in a Polish peatland where different drought intensities were simulated. We determined the diversity and functional community composition of plants and fungi, soil enzyme multifunctionality, dissolved organic matter quantity and quality, and ecosystem respiration. We focused on fungal diversity and community composition in the light of the role that fungi play as both decomposers of organic matter and root-associated mediators of belowground $\mathrm{C}$ transport and respiration (Clemmensen et al., 2013). We specifically tested which level of compositional and functional changes in plant and fungal communities in response to drought will lead to a shift in ecosystem respiration, and whether there are causal interactions between tipping events among trophic groups. We hypothesized that (i) drought will initiate a domino-like event within plant and

This article is protected by copyright. All rights reserved. 
fungal communities, including their interactions, that will shift peatland function. Consequently, we expect (ii) that the response of fungi to drought will trigger the first shifts in soil enzyme activity that will be exacerbated by the contemporary response of plant community. In turn, (iii) higher soil enzyme activity will stimulate ecosystem respiration by a domino effect. Our study emphasizes the importance of considering domino-effects within plant-soil interactions to better understand and predict how a changing climate can shift ecosystem function.

\section{Material and methods}

\section{Study site and water table manipulation}

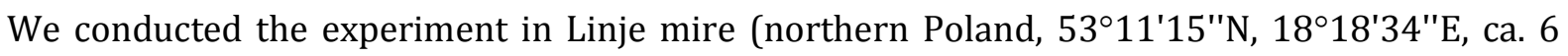
ha), a poor fen with ombrotrophic vegetation (Lamentowicz et al., 2016). The moss layer was dominated by Sphagnum fallax while the herbaceous layer was characterized by Betula nana the graminoids Eriophorum vaginatum, Carex rostrata and the ericoids Oxycoccus palustris. The water table manipulation consisted of three water-table treatments (Wet, Ambient and Dry) randomly assigned to 18 homogeneous plots $\left(1 \mathrm{~m}^{2}\right)$ in terms of vegetation (i.e. 6 plots per combination) (Lamentowicz et al., 2016). The 18 plots were spread over a hectare with minimal distance between two plots of c. $1 \mathrm{~m}$ and maximal distance of c. $25 \mathrm{~m}$. The water level manipulation was obtained by lowering (Wet) or raising (Dry) the top $30 \mathrm{~cm}$ of the vegetation carpet. In the Wet plots, we firstly cut and removed four peat monoliths $(50 \times 50 \times 30 \mathrm{~cm}$; 1 x w x h) and the $10 \mathrm{~cm}$ of underlying peat that was kept aside. The peat monoliths were then placed back in the plot so that the moss surface was now $10 \mathrm{~cm}$ lower in comparison to the Ambient plots. In the Dry plots a similar monolith removal was performed. In these plots, however, the $10 \mathrm{~cm}$ peat material previously removed from the Wet plots was added to the plots, after which the vegetated monolith were placed back. This procedure resulted in the moss surface to be raised by $10 \mathrm{~cm}$ in comparison to the Ambient plots. In Ambient plots, the four peat monoliths

This article is protected by copyright. All rights reserved. 
were cut, removed and replaced on the same position. All 18 experimental plots were bordered by a plastic sheeting (15 cm height) to maintain the moss carpet. An elevated boardwalk was constructed to prevent damages from trampling during the measurements and the maintenance works. We further selected six other plots that remained untouched to test for the peat cutting and moving effects on the biotic and abiotic variables that were measured. Overall, we did not find significant effects of the cutting and moving phases for most of the measured variables in this study (Table S1). The water table manipulation experiment started in mid-May 2012 but we left the system recovering for one year before starting the measurements. We collected samples after 12 (mid-May 2013), 15 (mid-August 2013), 18 (early-November 2013) and 27 (midAugust 2014) months from the beginning of the experiment. These dates were chosen to both coincide with natural water level variations (Fig. 2) and different seasons.

\section{Local-scale environmental conditions}

In each plot, air (30 cm above the Sphagnum carpet; HOBO U23 Pro v2 data loggers) and peat (5 cm depth; 5TM sensor Decagon Devices, Inc., USA) temperatures were recorded continuously every 10 minutes (Lamentowicz et al., 2016). Water Table Depth (WTD) was recorded using HOBO U20-001-01 pressure data loggers (Onset Computer Corporation, USA) every 3 hours in four piezometers within the experimental site. WTD for each plot was then corrected using the averaged WTD across the experimental site and the averaged distance from the Sphagnum layer to the water table depth of each plot (corrections were adjusted several times per year). As a result, strong negative WTD values indicate dry conditions, while WTD values close to 0 indicate wet conditions. Precipitation was recorded continuously throughout the entire study period using a tipping bucket Rain Gauge Smart Sensor (S-RGB-M002, Onset Computer Corporation, USA) with a resolution $0.2 \mathrm{~mm}$. Vapor Pressure Deficit (VPD) was calculated following Abtew and Melesse (2013).

This article is protected by copyright. All rights reserved. 


\section{Vegetation survey}

We assessed the seasonal dynamic of plant species cover at each date in each plot using pictures taken in $50 \times 50 \mathrm{~cm}$ subplots (Buttler et al., 2015). We took high-resolution images based on four $25 \times 25 \mathrm{~cm}$ quadrats and used a grid of 100 points laid on each quadrat to quantify species overlaying the grid intersects (Buttler et al., 2015). This technique did not allow accounting for the vertical biomass distribution and may underestimate the abundance of certain species such as Sphagnum fallax. However, the bias was similar in each plot, thus making species frequencies comparable among treatments, and did not further influence the response of plant species to treatments. We especially distinguished the graminoid cover from the ericoid cover as these two plant types differ in productivity, litter, root inputs and plant-fungal associations, and as such may have different effects on ecosystem C dynamic (Robroek et al., 2015; Walker et al., 2015; Robroek et al., 2016; Walker et al., 2016).

\section{Water-extractable organic matter quantity and quality}

Water-extractable organic matter (WEOM) was extracted from $S$. fallax shoots $(100 \mathrm{~g} ; 0-8 \mathrm{~cm}$ depth) collected at each sampling period in all manipulated plots following Delarue et al. (Delarue et al., 2011). The water extract was then pre-filtered through a gauze-membrane (1 $\mathrm{mm}$ pore size) to remove Sphagnum remains and filtered at $0.45 \mu \mathrm{m}$ through a glass fibre filter. Sphagnum remains were dried at $60^{\circ} \mathrm{C}$ for $48 \mathrm{~h}$. Dissolved organic carbon and nitrogen (WEOC and WEON, respectively) concentration in the WEOM were quantified by combustion using a TOC analyser (Shimadzu TOC-V CPH) and expressed as mg C or $\mathrm{N} \mathrm{g}^{-1} \mathrm{dw}$ of Sphagnum. WEOM aromatic content and molecular weight was measured using specific UV absorbance at $254 \mathrm{~nm}$ $\left(\mathrm{SUVA}_{254}\right)$ and absorbance measurements between 250 and $465 \mathrm{~nm}$ (15 wavelengths in total) in $200 \mu \mathrm{L}$ sample aliquots in 96-well quartz microplate using a BioTek SynergyMX spectrofluorometer (Jaffrain et al., 2007). Spectral slopes $\left(S_{250-465,} \mathrm{~nm}^{-1}\right)$ were calculated using linear least squares regressions with Ln-transformed absorptions. High $\mathrm{SUVA}_{254}$ value indicates This article is protected by copyright. All rights reserved. 
a high aromatic content while high $S_{250-465}$ values indicate low molecular weight material and/or decreasing aromaticity of the WEOM (Hansen et al., 2016).

\section{Fungal DNA analyses and bioinformatics}

DNA was extracted with MoBio Power Soil DNA isolation kit (Carlsbad, CA USA) according to the instructions provided by the supplier. PCR amplification follows the protocol of Amaral-Zettler et al. (2009). The eukaryotic PCR primers 1380F (CCCTGCCHTTTGTACACAC) and 1510R (CCTTCYGCAGGTTCACCTAC) targeting V9 region of the SSU rRNA gene were used. Forward primers were tagged on the $5^{\prime}$ end with a 10 nucleotides strand, specific to each sample. The PCR reactions mix $\left(20 \mu \mathrm{l}\right.$ reaction volume) consisted of 1 U GoTaq ${ }^{\circledR}$ G2 DNA Polymerase (Cat No.: M7845, Promega, Switzerland), 1 X Colorless GoTaq® Reaction Buffer, $300 \mu$ M dNTPs (Cat No.: U1420, Promega, Switzerland) and $0.3 \mu \mathrm{M}$ of each primer. The PCR conditions were as follows: initial activation step at $95^{\circ} \mathrm{C}$ for $3 \mathrm{~min}$, followed by 303 -step cycles (consisting of 94 ${ }^{\circ} \mathrm{C}$ for $30 \mathrm{~s}, 57^{\circ} \mathrm{C}$ for $30 \mathrm{~s}$ and $72^{\circ} \mathrm{C}$ for $1 \mathrm{~min}$ ) and a final 10 -min extension at $72{ }^{\circ} \mathrm{C}$. The PCR products were purified with Wizard® SV Gel and PCR Clean-Up System (Promega, Madison, WI USA). Sequencing was performed with Illumina's HiSeq technology, using V3 chemistry by Fasteris SA, Switzerland.

The bioinformatics pipeline included quality check (Phred score filtering, elimination of reads without perfect forward and reverse primers) and removal of rare sequences (sequences occurring less than three times in the full data set or in less than two distinct samples). Sequences were clustered into Operational Taxonomic Units (OTUs) with the Swarm algorithm (Mahé et al., 2014), and the number of reads of a given OTU counted in each sample. The most abundant sequence of each OTU was selected as the representative to be aligned (BLASTn) against the UNITE (www.unite.ut.ee) data base (Kõljalg et al., 2013). For each query, we thus

This article is protected by copyright. All rights reserved. 
considered the 10 best-matching references to annotate our global sequences as accurately as possible (Tedersoo et al., 2014). OTUs with $e$-values $<e^{-50}$ and bit-scores $>100$ were assigned to species level if homology was $100-97 \%$, genus for $96.9-93 \%$, family or order for $92.9-80 \%$. OTUs with $e$-values $>e^{-20}$ were considered as "unknown", while those with $e$-values between $e^{-20}$ and $e^{-50}$ were carefully checked against the 10 best matches and implemented in the PlutoF workbench (Kessy Abarenkov et al., 2010) for accurate assignment. Identified OTUs were further assigned to functional guilds using FUNGuild (Nguyen et al., 2016) with some modifications according to literature: undefined root endophyte, ectomycorrhizal fungi, ericoid mycorrhizal fungi, lichenized fungi, plant pathogen, animal pathogen, mycoparasite, undefined saprotroph, leaf/litter saprotroph, wood saprotroph and unknown. All details are provided in Table S2.

\section{Soil enzyme multifunctionality and ecosystem respiration}

The soil enzyme multifunctionality was analysed using a catabolic response profile approach by measuring enzymatic activities of three hydrolytic- and two oxidative- $\mathrm{C}$ degrading enzymes, one hydrolytic $\mathrm{C} / \mathrm{N}$-degrading enzyme, three aminopeptidases (N-cycle), and one acid-phosphatase (P-cycle; see Table S3 for details). Enzyme activities were quantified in Sphagnum litter (0-8 cm depth; approximately $300 \mathrm{~g}$ of fresh Sphagnum litter) as relative enzyme activity, i.e. enzymes activities were assessed under saturating substrate conditions and stable temperature $\left(25^{\circ} \mathrm{C}\right)$. Enzymes were quantified in microplates following Jassey et al. (Jassey et al., 2012; 2016). Fluorescence of hydrolases was monitored spectrophotometrically with an excitation wavelength of $365 \mathrm{~nm}$ and emission detection at $450 \mathrm{~nm}$ (Biotek, SynergyMX) while oxidation rates of oxidases were monitored spectrophometrically at $600 \mathrm{~nm}$ (Table S3). All enzymatic activities were converted to nanomoles per gram dry weight per min (nmol min-1 $\mathrm{g}^{-1}$ DM).

This article is protected by copyright. All rights reserved. 
Ecosystem $\mathrm{CO}_{2}$ respiration $\left(\mathrm{R}_{\mathrm{ECO}}\right)$ was measured at the same periods using a dynamic closed chamber system consisting of an infrared gas analyzer EGM-4 and a darkened net canopy assimilation chamber CPY-4 (PP-Systems International, Inc., USA). Each measurement was carried out by putting the chamber on $20 \mathrm{~cm}$ diameter collar inserted into a Sphagnum dominated (vascular plant free) surface at the beginning of the experiment. The $\mathrm{CO}_{2}$ concentration was recorded over 2 minutes at 4 seconds' intervals. At each field campaign, measurements were performed repeatedly during a full day, using three analyzers and a stochastic sampling scheme for the path of plot measurements. Fluxes are expressed in $\mu \mathrm{mol} \mathrm{CO} \mathrm{m}^{-2} \mathrm{~s}^{-1}$.

\section{Numerical analyses}

Deconstruction of trend and seasonal figures in climatic time series. Given WTD variations were strongly collinear with sampling dates (Fig. 1), we deconstructed the WTD time series into its trend and seasonal components. The trend component reflects the long-term progression of the series such as an increasing or decreasing direction in the data. The seasonal component reflects the seasonal patterns in the time series (e.g. repeated periodic fluctuations). The seasonal component was calculated through a fixed period of 92 days. We extracted these two components using additive models (Brockwell \& Davis, 2016). The trend component was removed by smoothing the time series using a centred moving window average (period of 92 days). Removing the trend from the time series resulted into a new time series where seasonal figure is clearly exposed. From this resulting seasonal figure, we computed an average seasonality for each time unit (day), over all periods. The seasonal figure was finally centred. We repeated that procedure on each plot and each climatic time series (WTD, temperature, and VPD) and averaged the seasonal figure of each time series as a proxy for 'climatic seasonality'. Deconstruction of the time series was achieved using the decompose $\mathrm{R}$ package ( $\mathrm{R}$ Core Team 2015).

This article is protected by copyright. All rights reserved. 
Response of belowground components to drought. We evaluated the effect of water level treatments, trend in WTD and climatic seasonality on plants cover, enzymatic activities, fungal richness and WEOM properties (WEOC, WEON, SUVA $\left.254, S_{250-465}\right)$ over time (after 12, 15, 18, 27 months) using linear mixed effect models. All models were fitted including plot nested into climatic seasonality as a random effect on the intercept to correct for the inflation of the residual degrees of freedom that would have occurred if we were using repeated measurements as true replicates (Pinheiro \& Bates, 2000). The nlme R package was used to run these models. The Tukey's HSD test was used for post hoc comparisons among treatments. We then performed non-metric multidimensional scaling (NMDS) and a principal component analysis (PCA) for a specific interpretation of fungal OTU communities' structure and enzyme activities' patterns (both data sets were log-transformed), respectively, at each period and for each treatment. Sites scores from the PCA were further used as a proxy for enzyme multifunctionality $\left(M_{e n z}\right)$-an averaging method that attempts to summarize multiple enzyme activities so that high values of $M_{\text {enz }}$ mean high values of many of, but not necessarily all, the enzyme activities included (Maestre et al., 2012). We extracted the site scores from these two ordinations and subjected them to linear mixed effect models, as described above, to interpret significant interactions between shifts in fungal communities (or enzymatic patterns) and WTD variations.

Identifying tipping points. We used broken-line regression models (segmented method) to identify possible tipping points in key descriptors such as enzyme multifunctionality, plant cover, and $S_{250-465}$. This method is the most adequate method to determine tipping points in ecosystem components (Vanacker et al., 2015). Segmented method tests whether the relationship between two variables is piecewise linear, namely represented by two or more straight lines connected at unknown changing points. The output of this analysis provides tipping point estimates with relevant uncertainty; in other words, it gives estimated, and not fixed, changing points with a range where a tipping point could be situated. We used segmented

This article is protected by copyright. All rights reserved. 
R package (Muggeo, 2008) to perform these analyses. We further parsed fungal OTU community response to water level gradient using Threshold Indicator Taxa ANalysis (TITAN). This method can reveal sharp, nonlinear transitions in community data (see Baker \& King, 2010 for a full description). Briefly, TITAN identifies the optimum changing point of every species frequency and abundance along a continuous variable $x$ using the indicator species analysis approach that partition the data along $x$. Indicator species analysis measures how well a taxon is associated with the group either above or below a certain value on an environmental gradient (the water level in this case) (Dufrêne \& Legendre, 1997). Each taxon is assigned to an indicator value (IndVal scores) that take into account the frequency of occurrence, the proportional abundance and directionally of taxa responses in these two groups. IndVal scores are scales between $0 \%$ and $100 \%$ with a value of 100 indicating that a taxon was collected in every sample within a group and not the other group. In TITAN, IndVal scores are calculated for all species for all possible change points along the environmental gradient (every observed value of $x$ are candidate change points), with permutation tests to assess the uncertainty in these scores (Baker \& King, 2010). TITAN empirically distinguishes increasing (positive response) and decreasing (negative response) taxa at each candidate change points, whereas taxon-specific response magnitude is normalised as $z$ scores (based on SD and mean of permutations) and sums for positive $\left[\operatorname{sum}\left(\mathrm{z}^{+}\right)\right]$and negative $[\operatorname{sum}(\mathrm{z}-)]$ responses for each possible change point along the gradient. TITAN thus detects changes in species distributions along a gradient and assesses synchrony among species changing points as evidence for community thresholds. Sum(z) peaks highlight values of the environmental variable around which many taxa exhibit strong directional changes in abundance representing community thresholds. The quality and estimation of the critical tipping point area in fungal community was tested using 1000 permutations and 500 bootstrap replicates (resampling with replacement) using custom TITAN2 R package (Baker \& King, 2010). We transformed the raw OTU sequence dataset using a centred log transformation.

This article is protected by copyright. All rights reserved. 
Drivers of ecosystem $\mathrm{CO}_{2}$ respiration. The response of ecosystem respiration to drought can be determined by numerous interconnected biotic mechanisms that operate simultaneously. One approach to studying such complex interactions is structural equation modelling (SEM; Grace et al., 2014). Following current knowledge of peatland responses to drought, we developed an $a$ priori model of hypothesized relationships within a path diagram (Fig. 1, Table 1), allowing a causal interpretation of the linkages between WTD, plant and fungal community composition, enzyme multifunctionality, WEOM quality and $\mathrm{R}_{\mathrm{ECO}}$ (Grace \& Keeley, 2006). We first ran the $a$ priori model on the entire data set to identify the main drivers of $\mathrm{R}_{\mathrm{ECO}}$. Our SEM approach was semi-exploratory in that while we worked to address general hypothesis embodied in a path diagram, the precise variables (for example Graminoid cover versus Sphagnum cover) to use were determined empirically based on the outputs of the full model (Fig. S1) and by step-wise exclusion/selection of variables, as estimated by Akaike Information Criterion (AIC) (Grace et al., 2016). The critical tipping point area among the plant-soil microbial drivers of $R_{\mathrm{ECO}}$ was identified using a smoothing SEM approach. Smoothing was achieved by running movingwindow SEMs along the WTD continuum. First we ranked the entire data set from lower to higher WTD. Then, we sequentially changed the subset of plots (= window) by adding the next more wet plot and discarding the least wet one. We used a window of 26 consecutive samples across the WTD gradient (total of transits $=29$ ) and quantified for each window the variation of $\mathrm{R}_{\mathrm{ECO}}(\mathrm{R}$-square value) explained by the model. Multiple window sizes were tested initially, all showing similar patterns; the 26-sample window size was, however, optimal for interpretation without losing too much fit in SEMs. Path analyses were performed using the sem R package and moving window SEMs using personal $\mathrm{R}$ codes (movingsem function available at https://doi.org/10.5281/zenodo.913424).

The degree of response of ecosystem respiration's drivers (D) to drier conditions was calculated using standardized effect sizes (SES), as follow:

This article is protected by copyright. All rights reserved. 


$$
\mathrm{SES}_{\mathrm{D}}=\left(\mathrm{D}_{\mathrm{i}}-\mathrm{D}_{\mathrm{wet}}\right) / \mathrm{SD}(\mathrm{D})
$$

where $D_{i}$ is a value of $D$ along the water level gradient, $D_{\text {wet }}$ the value of $D$ that corresponds to the wettest WTD along the gradient and SD(D) the standard deviation of D. SES was calculated for each driver of ecosystem $\mathrm{CO}_{2}$ respiration found in SEM and then averaged.

\section{Results}

\section{Seasonal variation of hydrological and climatic parameters}

WTD significantly differed between the three water level treatments $(P<0.001$; Fig. 2a). On average, the water level was 37\% lower in the Dry treatment than in the Wet treatment $(P<$ $0.001)$ and $28 \%$ lower than in the Ambient treatment $(P<0.001)$. Similarly, the water level in Ambient treatment was $13 \%$ lower than in the Wet treatment $(P<0.01)$. Furthermore, the water level significantly and similarly decreased over time in all treatments (date: $P=0.0001$; date $\mathrm{x}$ WTD treatment: $P=0.66$ ). Especially, we observed an equally important drop of the water level in all treatments during summer 2014, with a mean drop of $21 \mathrm{~cm}$ between mid-May 2014 and mid-August 2014 (Fig. 2a-b). Greater vapour pressure deficit between 2013 and 2014 further corroborates these results by indicating warmer and drier conditions in 2014 than in 2013 (Fig. S2). Overall, the temporal and natural fluctuations of water table depth spanned over a gradient from -40 to $-5 \mathrm{~cm}$. Decomposition of the trend and seasonal components of WTD showed that temporal variations of WTD remained similar in 2013 and 2014 but with a decreasing trend in 2014 compared to 2013 (Fig. 2b).

\section{Response of plant community to water table depth}

Trend in water table depth had larger effects on plant cover than climatic seasonality (Table S4). Under Ambient conditions, vascular plants benefited from decreasing water level with an

This article is protected by copyright. All rights reserved. 
increase of their cover by $47 \%$ after 27 months compared to the beginning of the experiment $(P$ $<0.01$, Fig. 3a-b). This increase was particularly driven by the graminoids $\left(F_{1,70}=68.8, r=0.70\right.$ and $P<0.01$ ), especially Eriophorum vaginatum (Fig. S3). On the opposite, decreasing water level reduced Sphagnum cover in Ambient plots by $77 \%$ after 27 months from the beginning of the experiment $(P<0.01)$. These changes decreased the moss/graminoid ratio from 8 to 0.17 from the beginning to the end of the experiment. Beyond natural variations of water table, vascular plants and Sphagnum either benefited or suffered from water level manipulations. Sphagnum plants always had a lower cover in Dry treatments compared to Ambient and Wet $\left(F_{2,64}=45.1, P<0.001\right)$, especially after 27 months when they almost disappeared from the plant community (Fig. 3a). On the opposite, wetter conditions promoted Sphagnum cover that was on average 33\% higher in Wet plots compared to Ambient plots $(P<0.01)$. We found opposite effects for vascular plants as their cover was on average 10\% higher in Dry treatment and 18\% lower in Wet treatment compared to Ambient conditions, respectively $\left(F_{2,64}=24.6, P<0.001\right.$; Fig. 3a). Particularly, we found that the dominant ericoid Oxycoccus palustris had a consistent lower cover in Wet plots compared to Ambient and Dry plots (Fig. S3). We further found that the vascular plant community shifted from an ericoid-dominance at the beginning of the experiment towards an equal dominance between graminoids and ericoids (Fig. S3a-b) along with decreasing water table, particularly at a water level of c. $-20 \mathrm{~cm}$ (Fig. 3b).

\section{Response of dissolved organic matter (WEOM) to water table depth}

The quantity and quality of WEOM significantly varied during the season but they were mainly influenced by trends in WTD (Table S4). Under Ambient conditions, both WEOC $(r=0.46, P<$ $0.01)$ and the spectral slope $\left(S_{250-465}\right)$ of WEOM $(r=0.71, P<0.01$, Fig. 4a; Fig. S3c $)$ increased along with the decrease of the water level, while WEON remained stable ( $P=0.66$; Fig. S3d). SUVA $_{254}$ decreased along with decreasing water level $(r=0.56, P<0.01$; Fig. S3e). Whilst WEOC, WEON and SUVA 254 did not respond to water level treatments, the spectral slope $\left(S_{250-465}\right)$ of

This article is protected by copyright. All rights reserved. 
WEOM was lower in Wet plots compared to Ambient and Dry conditions, especially after 15 and 18 months (Fig. 4a). Altogether, these results indicate a lower aromaticity and/or lower molecular weight of WEOM along with decreasing WTD, and that Dry treatment enhanced such trend. Specifically, WEOM was less and less aromatic until a water level of c. $-24 \mathrm{~cm}$ was reached and then it remained more stable (Fig. 4b). This changing point was concomitant with the point where graminoids and ericoids started to be co-dominant (Fig. 3b).

\section{Response of fungal soil community and enzyme multifunctionality to water table depth}

Fungal OTU richness under Ambient treatment increased with the natural decreasing of WTD $(r$ $=-0.76, P<0.01)$. The fungal OTU richness was also consistently higher in Dry treatment compared to Ambient and Wet treatments, respectively $\left(F_{2,49}=9.8, P=0.03\right.$; Fig. S4). NMDS analysis showed that fungal OTU composition differed over the natural WTD gradient (NMDS axis 1) and among Wet, Ambient and Dry treatments (NMDS axis 2; Fig. S5a). Using threshold indicator taxa analysis (TITAN), we identified 205 OTUs (out of 489) that showed a significant changing point along the WTD gradient (Fig. 5a), predominantly at WTD between -28 and -21 cm. Among them, 174 OTUs were closely related to dry conditions (Fig. 5a), especially saprotrophs (Fig. 5b). As a result, fungal community composition strongly converged at a WTD of c. $-26.8 \mathrm{~cm}$ (Fig. 5c) indicating a community-level ecological threshold.

Trend in water table depth had larger effects on enzymatic activities than seasonality (Table S4). PCA analysis showed that enzymatic patterns differed over the natural WTD gradient (PCA axis 1) and among Wet, Ambient and Dry treatments (PCA axis 2; Fig. S5b). In particularly, Dry treatment tended to promote hydrolytic- $\mathrm{C}$ and chitinase enzyme activities compared to Wet treatment, while peptidases and phosphatase either decreased (e.g. LAP, 16\%) or remained stable (Fig. S6, Table S4). Broken-line analysis further showed that enzyme

This article is protected by copyright. All rights reserved. 
multifunctionality strongly increased once the water level crossed the depth of $-25.8 \mathrm{~cm}$ (Fig. 5d). Such pattern was mostly driven by the response of hydrolytic enzymes (Fig. S7), which all showed a significant changing point between -25 and $-28 \mathrm{~cm}$ along the WTD gradient (Table S5). Oxidases either decreased (peroxidases, $r=-0.61, P<0.001$ ) or remained stable (phenoloxidases, $r=0.004, P=0.94$ ) along the water level gradient.

\section{Tipping point in ecosystem $\mathrm{CO}_{2}$ respiration}

Ecosystem $\mathrm{CO}_{2}$ respiration was more influenced by the trend in water table depth than climatic seasonality (Table S4). In particularly, ecosystem respiration suddenly increased once the water level dropped below c. $-25 \mathrm{~cm}$ (Fig. 5e), but no effects of water level treatment were found (Fig. S8). Moving window SEMs showed that the response of ecosystem $\mathrm{CO}_{2}$ respiration (R-squared value) to shifts in plant and fungal communities, including their interactions with enzymes, could be divided into three phases: a first phase with low $R^{2}$ values (phase 1 , WTD $=-16$ to -21 $\mathrm{cm}$ ), a second transition phase with increasing $R^{2}$ values (phase $2, \mathrm{WTD}=-21$ to $-24 \mathrm{~cm}$ ) and a third phase with high $R^{2}$ values (phase 3, WTD > -24 cm; Fig. 6a, Table S6). These three phases correspond to different water table levels ranged from wet to dry, respectively. When averaged for each phase, SEMs showed that increased ecosystem $\mathrm{CO}_{2}$ respiration was mostly mediated by the direct influence of graminoids on WEOM quality, which in turn, influenced fungal community composition and enzyme activities (Fig. 6b). SEMs further showed that the influence of fungal community composition on ecosystem $\mathrm{CO}_{2}$ respiration was either direct, or indirect through enzyme multifunctionality. In general, SEM moving window analysis showed progressive bifurcations from the 'wet' towards the 'dry' phase in the drivers of ecosystem $\mathrm{CO}_{2}$ respiration. First, the WTD had an effect on plant and fungal communities (Fig. 6b, Table S6). Second, graminoids influenced WEOM quality, while the effect of WEOM quality on enzyme multifunctionality increased over the gradient. Finally, the effect of fungi and enzymes on ecosystem $\mathrm{CO}_{2}$ respiration increased in intensity along the water level continuum (Fig. 6b, Table

This article is protected by copyright. All rights reserved. 
S6). More precisely, we found that although the drivers of ecosystem respiration responded to lowering water level, their effect on respiration was significant only once a threshold was passed in their degree of response (Fig. 6c).

\section{Discussion}

The likelihood of sharp functional shifts in natural ecosystems is expected to increase as climate change intensifies (Hoover \& Rogers, 2016), in particular in response to repeated drought events (Angeli et al., 2004). Pinpointing the specific triggers of such ecosystem shifts is challenging. One of the big question is which combination of climatic and biotic changes causes ecosystems to cross a tipping point in their functioning. In this study, we identified how the individual response of plants and soil fungi along a moisture gradient pushes peatland ecosystem respiration towards an alternative state. The results confirmed our hypothesis that drought can lead to a domino-like event where positive feedbacks among plants and fungi force the system towards a critical tipping point amplifying small initial changes in ecosystem $\mathrm{CO}_{2}$ respiration. Our analysis based on moving window SEM showed that substantial changes in ecosystem respiration occurred when water level crossed the tipping point of $-24 \mathrm{~cm}$. Before this critical point, our results showed a transition phase between -19 and $-23 \mathrm{~cm}$ where shifts in plant and fungal communities progressively triggered shifts in ecosystem $\mathrm{CO}_{2}$ respiration. Although the ultimate causality could not be established from SEMs, the joint consideration of the dynamics of ecosystem respiration and the successional trends in plant and fungal community structure along the water level gradient represents a major advance in understanding ecological thresholds (Briske et al., 2006; Kreyling et al., 2014).

The impact of drought on ecosystem $\mathrm{C}$ dynamics involves multiple interactions among abiotic, plant and soil microbiota components (Suding \& Hobbs, 2009; Scheffer et al., 2012). Our results demonstrate that simultaneous, and sometimes antagonistic, responses within fungal and plant assemblages collectively pushes peatland processes beyond an alternative functional This article is protected by copyright. All rights reserved. 
state. Consistent with previous studies (Yuste et al., 2011; de Vries et al., 2012; Barnard et al., 2013; Asemaninejad et al., 2017), fungi displayed a marked resistance to drought and were even able to overcome the physiological stress imposed by decreasing water table depth. We observed greater fungal richness under dry conditions compared to wet conditions, both over time and among water level treatments. Fungi are generally most competitive under an oxic environment (Jaatinen et al., 2007; Bragazza et al., 2015), although water table depth was probably low enough $(>-10 \mathrm{~cm})$ at the beginning of the experiment to allow the oxygen diffusion through the peat surface (Estop-Aragonés et al., 2012). Another reason for the fungal resistance to strong water level drop is the hydraulic redistribution of water by mycelia networks. Fungi are able to compensate unfavourable soil moisture conditions as long as water is available in other zones of the mycelia network (Guhr et al., 2015), which was the case at the deeper water table level. Most importantly, we found that saprotrophic fungi gradually increased alongside with decreasing water level; they even predominated the fungal community composition once the water level passed $-25 \mathrm{~cm}$. This trend fits well with SEM outputs where enzyme multifunctionality regulates ecosystem $\mathrm{CO}_{2}$ respiration. By producing a cocktail of extracellular enzymes (Crowther et al., 2012), saprotrophic fungi break down a wide range of organic compounds from simple and labile monomers to complex and recalcitrant polymers, which are rapidly consumed and largely respired.

Alongside with an increase of saprotrophic fungi, ecosystem $\mathrm{CO}_{2}$ respiration was indirectly driven by drastic changes in vegetation composition. Graminoids gradually replaced Sphagnum mosses along the gradient with a parallel change in the interactions between plants and soil decomposers activity. Greater tolerance to drier conditions by graminoids compared to Sphagnum and shrubs is probably the result of anatomical and/or physiological traits of graminoids that protect them against drought-induced physiological damages (Carlquist, 2012). For example, their deep rooting system allows them to access water deeper in the peat when

This article is protected by copyright. All rights reserved. 
necessary (Buttler et al., 2015). We further observed that the spectrophotometric slope coefficient $S_{250-465}$ of WEOM, an index inversely related to the molecular weight and aromaticity of dissolved organic matter (Hansen et al., 2016), was greater under low water level and high graminoid cover. In accordance with other studies (Wang et al., 2015; Robroek et al., 2016; Dieleman et al., 2017), we interpret these results as evidence that the quality of DOM was controlled by vascular plants, and especially by graminoids which released less aromatic C compounds presumably as root exudates (Crow \& Wieder, 2005). Root-exudates are indeed predominantly composed of simple labile C compounds, such as sugars (Gunina \& Kuzyakov, 2015), easily available for microorganisms and easily respired as $\mathrm{CO}_{2}$ (Werth \& Kuzyakov, 2008). As fungi are particularly prone to use root exudates as energy source (Steinauer et al., 2016), our results suggest that high graminoid cover stimulates fungal activity by providing labile $\mathrm{C}$, thereby increasing the fungal respiration. An alternative or additional cause for the decreasing aromaticity of DOM could result from higher peat oxygenation. Oxygen availability may stimulate oxygen-dependent enzyme activities (phenoloxidases and peroxidases) that decompose aromatic compounds such as polyphenols (Fenner \& Freeman, 2011). However, oxidases did not increase in response to drier conditions and were not involved in decreasing aromaticity of DOM (Fig. S7 and S10). Furthermore, we cannot exclude the possibility that living plants, especially graminoid plant roots and shrubs such as Betula nana, also contributed to increase ecosystem $\mathrm{CO}_{2}$ respiration either directly or indirectly through plant-soil feedbacks (Deslippe et al., 2016; Walker et al., 2016). Yet, previous findings showed that microbial heterotrophic respiration substantially contributes to ecosystem respiration in peatlands ( 70\%) (Dorrepaal et al., 2009). Although these findings do not exclude a contribution of plant root to ecosystem respiration in our plots, it suggests that the increase of ecosystem respiration was not primarily driven by autotrophic (= plant root) respiration.

Ecosystem $\mathrm{CO}_{2}$ respiration was the greatest at the drier end of the water table gradient when graminoids and saprotrophic fungi became prevalent. We deduce that plant and fungal communities' responses to drought were large enough such that abrupt increased of ecosystem

This article is protected by copyright. All rights reserved. 
respiration was driven by the resultant of these changes, i.e., persistent labile $C$ inputs from graminoids that were degraded and respired by saprotrophic fungi. These results show that shift in ecosystem respiration critically depends on changing dominance within key trophic groups, but also on their degree of response to drought. Moreover, we provide evidence that biotic communities are affected by extreme drought up to a point where changing dominance at one trophic level (tipping point in plants $=-20 \mathrm{~cm}$ ) causes a domino effect on other trophic levels (tipping point belowground $\sim-24 \mathrm{~cm}$ ) cascading into a systemic transition. Complex network modelling frameworks recently suggested that tipping points in the underlying interactions among species may be the main driver of ecosystem shifts (Scheffer et al., 2012; Yletyinen et al., 2016). Our findings extent these results by showing that sharp functional transitions in ecosystems may depend on the dominance replacement of sensitive by tolerantspecific species with the same function that together interact and drive specific ecosystem processes.

Our results have important implications for predicting the response of peatland $\mathrm{C}$ dynamic to drought by suggesting that Sphagnum-dominated peatlands with a water level lower than $-24 \mathrm{~cm}$ may undergo a different functional state, with large contrasts in ecosystem $\mathrm{CO}_{2}$ respiration. Recent studies showed that the current rate of climate change in northern biomes already shifted vegetation composition towards vegetation composition comparable to our study (Walker et al., 2006; Elmendorf et al., 2012; Lesica \& Crone, 2017), with risks of substantive C loss (Ward et al., 2013; Bragazza et al., 2016). The range beyond which particular vegetation changes impact ecosystem functioning has been so far overlooked. In light of our findings, we suggest that droughts may turn peatlands into a $\mathrm{C}$ source once functionally interdependent shifts in plants and soil microbiota would become prevalent. Whilst we generalise from a limited set of ecosystem functions over a short-temporal scale, we cannot exclude that the system could follow a reverse pathway if the water level increases again (which is not currently the case, Fig. S11) or remains at the 'dry stage' considering the legacy effects of

This article is protected by copyright. All rights reserved. 
drought on plant-soil interactions (Kaisermann et al., 2017). Anyhow, we provide empirical understanding about the mechanisms pushing ecosystems beyond a threshold in response to climate change. The joint consideration of domino-like events within different trophic levels pave the way for detecting ecosystem shifts, and is an important step towards a truly mechanistic understanding that consider the non-linear nature of ecosystem response to climate change.

\section{Acknowledgments}

This research is part of the CLIMPEAT project (PSPB-013/2010), through the Swiss Contribution to the enlarged European Union (www.climpeat.pl). We acknowledge the support of SCIEX Scientific Exchange Programme between Switzerland and the New Member States of the European Union Fellow - Monika Reczuga: Project CLI-MIC - Assessing the Responses of Peatland Micro-Eukaryotes to Climate Change Using Next Generation Sequencing. The study was also supported by the grant of Polish National Science Centre no. 2015/19/N/NZ8/00172: An impact of climate change (warming and drought) on biodiversity of micro-eukaryotes in peatlands - next generation sequencing and field experiment (PI Monika Reczuga). The authors are grateful to Andrew MacDonald for his statistical support on linear effect mixed models and Tom Walker for his advices on the manuscript.

\section{References}

Abtew, W., \& Melesse, A. (2013). Vapor Pressure Calculation Methods (eds Abtew W, Melesse A). Springer Netherlands, $10 \mathrm{p}$.

Amaral-Zettler, L.A., McCliment, E.A., Ducklow, H.W., \& Huse, S.M. (2009). A method for studying protistan diversity using massively parallel sequencing of V9 hypervariable regions of small-subunit ribosomal RNA genes. PLoS ONE, 4, e6372.

Angeli, D., Ferrell, J.E., \& Sontag, E.D. (2004). Detection of multistability, bifurcations, and hysteresis in a large class of biological positive-feedback systems. Proceedings of the National Academy of Sciences of the United States of America, 101, 1822-1827.

This article is protected by copyright. All rights reserved. 
Asemaninejad, A., Thorn, R.G., \& Lindo, Z. (2017). Experimental Climate Change Modifies Degradative Succession in Boreal Peatland Fungal Communities. Microbial ecology, 73, 521531.

Baert, J.M., Janssen, C.R., Sabbe, K., \& De Laender, F. (2016). Per capita interactions and stress tolerance drive stress-induced changes in biodiversity effects on ecosystem functions. Nature Communications, 7, 12486.

Baker, M.E., \& King, R.S. (2010). A new method for detecting and interpreting biodiversity and ecological community thresholds. Methods in Ecology and Evolution, 1, 25-37.

Bardgett, R.D., Freeman, C., \& Ostle, N.J. (2008). Microbial contributions to climate change through carbon cycle feedbacks. The ISME Journal, 2, 805-814.

Bardgett, R.D., Manning, P., Morriën, E., \& de Vries, F.T. (2013). Hierarchical responses of plantsoil interactions to climate change: consequences for the global carbon cycle. Journal of Ecology, 101, 334-343.

Barnard, R.L., Osborne, C.A., \& Firestone, M.K. (2013) Responses of soil bacterial and fungal communities to extreme desiccation and rewetting. The ISME Journal, 7, 2229-2241.

Berg, A., Findell, K., Lintner, B., Giannini, A., Senneviratne, S. L., van den Hurk, B., Lorenz, R. ... \& Milly, P. C. D. (2016). Land-atmosphere feedbacks amplify aridity increase over land under global warming. Nature Climate Change, 6, 869-874.

Bragazza, L., Bardgett, R.D., Mitchell, E.A.D., \& Buttler, A. (2015). Linking soil microbial communities to vascular plant abundance along a climate gradient. The New phytologist, $205,1175-1182$.

Bragazza, L., Buttler, A., Robroek, B.J.M., Albrecht, R., Zaccone C., Jassey, V.E.J., \& Signarbieux, C. (2016) Persistent high temperature and low precipitation reduce peat carbon accumulation. Global Change Biology, 22, 4114-4123.

Briske, D.D., Fuhlendorf, S.D., \& Smeins, F.E. (2006). A Unified Framework for Assessment and Application of Ecological Thresholds. Rangeland Ecology and Management, 59, 225-236.

Brockwell, P.J., \& Davis, R.A. (2016). Introduction to time series and forecasting, $3^{\text {rd }}$ edition (eds Brockwell PJ, Davis RA). Springer New York

Buttler, A., Robroek, B.J.M., Laggoun-Défarge, F., Jassey, V.E.J., Pochelon, C., Bernard, G. ... Bragazza, L. (2015). Experimental warming interacts with soil moisture to discriminate plant responses in an ombrotrophic peatland. Journal of Vegetation Science, 26, 964-974.

Canarini, A., Carrillo, Y., Mariotte, P., Ingram, L., \& Dijkstra, F.A. (2016). Soil microbial community resistance to drought and links to C stabilization in an Australian grassland. Soil Biology and Biochemistry, 103, 171-180.

Carlquist, S. (2012) Monocot Xylem Revisited: New Information, New Paradigms. The Botanical Review, 78, 87-153.

Clemmensen, K.E., Bahr, A., Ovaskainen, O. Dahlberg, A., Ekblad, A., Wallander, H., ... \& Lindahl,

This article is protected by copyright. All rights reserved. 
B.D. (2013). Roots and associated fungi drive long-term carbon sequestration in boreal forest. Science, 339, 1615-1618.

Crow, S.E., \& Wieder, R.K. (2005). Sources of CO2 emission from a northern peatland: root respiration, exudation, and decomposition. Ecology, 86, 1825-1834.

Crowther, T.W., Boddy, L., \& Hefin Jones, T. (2012). Functional and ecological consequences of saprotrophic fungus-grazer interactions. The ISME Journal, 6, 1992-2001.

Crowther, T.W., Todd-Brown, K.E.O., Rowe, C.W., Carey, J.C., Machmuller, M.B., Snoeck, B.L., ... \& Bradford, M.A. (2016). Quantifying global soil carbon losses in response to warming. Nature, 540, 104-108.

Dai, A. (2013). Increasing drought under global warming in observations and models. Nature Climate Change, 3, 52-58.

de Vries, F.T., Liiri, M.E., Bjørnlund, L., Bowker, M.A., Christensen, S., Setälä, H.M., \& Bardgett, R.D. (2012). Land use alters the resistance and resilience of soil food webs to drought. Nature Climate Change, 2, 276-280.

Delarue, F., Laggoun-Défarge, F., Buttler, A., Gogo, S., Jassey, V.E.J., \& Disnar, J-R. (2011). Effects of short-term ecosystem experimental warming on water-extractable organic matter in an ombrotrophic Sphagnum peatland (Le Forbonnet, France). Organic Geochemistry, 42, 10161024.

Deslippe, J.R., Hartmann, M., Grayston, S.J., Simard, S.W., \& Mohn, W.W. (2016). Stable isotope probing implicates a species of Cortinarius in carbon transfer through ectomycorrhizal fungal mycelial networks in Arctic tundra. The New phytologist, 210, 383-390.

Dieleman, C.M., Branfireun, B.A., \& Lindo, Z. (2017). Northern peatland carbon dynamics driven by plant growth form - the role of graminoids. Plant and Soil, 415, 25-35.

Dieleman, C.M., Branfireun, B.A., McLaughlin, J.W., \& Lindo, Z. (2016). Enhanced carbon release under future climate conditions in a peatland mesocosm experiment: the role of phenolic compounds. Plant and Soil, 400, 81-91.

Dise, N.B. (2009). Environmental science. Peatland response to global change. Science, 326, 810811.

Domínguez, M.T., Holthof, E., Smith, A.R., Koller, E., \& Emmett, B.A. (2017). Contrasting response of summer soil respiration and enzyme activities to long-term warming and drought in a wet shrubland (NE Wales, UK). Applied Soil Ecology, 110, 151-155.

Dorrepaal, E., Toet, S., van Logtestijn, R.S.P., Swart, E., van de Weg, M.J., Callaghan, T.V., \& Aerts, R. (2009). Carbon respiration from subsurface peat accelerated by climate warming in the subarctic. Nature, 460, 616-619.

Dufrêne, M., \& Legendre, P. (1997). Species assemblages and indicator species: the need for a flexible asymmetrical appraoch. Ecological Monographs, 67, 345-366.

Elmendorf, S.C., Henry, G.H.R., Hollister, R.D., Björk, R.G., Bjorkmqn, A.D., Callaghan, T.V., ... \&

This article is protected by copyright. All rights reserved. 
Wookley, P.A. (2012). Global assessment of experimental climate warming on tundra vegetation: heterogeneity over space and time. Ecology Letters, 15, 164-175.

Estop-Aragonés, C., Knorr, K.H., \& Blodau, C. (2012) Controls on in situ oxygen and dissolved inorganic carbon dynamics in peats of a temperate fen. Journal of Geophysical Research: Biogeosciences, 117, 10-14.

Felton, A.J., \& Smith, M.D. (2017). Integrating plant ecological responses to climate extremes from individual to ecosystem levels. Philosophical Transactions of the Royal Society B: Biological Sciences, 372, 20160142.

Fenner, N. \& Freeman, C. (2011). Drought-induced carbon loss in peatlands. Nature geoscience, 4, 895-900.

Fox, J.W. (2005). Interpreting the "selection effect" of biodiversity on ecosystem function. Ecology Letters, 8, 846-856.

Frank, D., Reichstein, M., Bahn, M., Thonicke, K., Frank, D., Mahecha, M.D., ... \& Zscheischler, J. (2015). Effects of climate extremes on the terrestrial carbon cycle: concepts, processes and potential future impacts. Global Change Biology, 21, 2861-2880.

Fuchslueger, L., Bahn, M., Fritz, K., Hasibeder, R., \& Richter, A. (2013). Experimental drought reduces the transfer of recently fixed plant carbon to soil microbes and alters the bacterial community composition in a mountain meadow. New Phytologist, 201, 916-927.

Fuchslueger, L., Bahn, M., Hasibeder, R., Kienz, S., Fritz, K., Schmitt, M., ... \& Richter, A. (2016). Drought history affects grassland plant and microbial carbon turnover during and after a subsequent drought event. Journal of Ecology, 104, 1453-1465.

Grace, J.B., \& Keeley, J.E. (2006). A structural equation model analysis of postfire plant diversity in California shrublands. Ecological applications: a publication of the Ecological Society of America, 16, 503-514.

Grace, J.B., Adler, P.B., Harpole, W.S., Borer, E.T., \& Seabloom, E.W. (2014). Causal networks clarify productivity-richness interrelations, bivariate plots do not. Functional Ecology, 28, 787-798.

Grace, J.B., Anderson, T.M., Seabloom, E.W., Borer, E.T., Adler, P.B., Stanley Harpole, W., ... \& Smith, M.D. (2016). Integrative modelling reveals mechanisms linking productivity and plant species richness. Nature, 529, 390-393.

Guhr, A., Borken, W., Spohn, M., \& Matzner, E. (2015). Redistribution of soil water by a saprotrophic fungus enhances carbon mineralization. Proceedings of the National Academy of Sciences of the United States of America, 112, 14647-14651.

Gunina, A., \& Kuzyakov, Y. (2015). Sugars in soil and sweets for microorganisms: Review of origin, content, composition and fate. Soil Biology and Biochemistry, 90, 87-100.

Hansen, A.M., Kraus, T.E.C., Pellerin, B.A., Fleck, J.A., Downing, B.D., \& Bergamaschi, B.A. (2016). Optical properties of dissolved organic matter (DOM): Effects of biological and photolytic degradation. Limnology and oceanography, 61, 1015-1032.

This article is protected by copyright. All rights reserved. 
Hicks Pries, C.E., Castanha, C., Porras, R.C., \& Torn, M.S. (2017). The whole-soil carbon flux in response to warming. Science, 355, 1420-1423.

Hoover, D.L., \& Rogers, B.M. (2016). Not all droughts are created equal: the impacts of interannual drought pattern and magnitude on grassland carbon cycling. Global Change Biology, 22, 1809-1820.

Jaatinen, K., Fritze, H., Laine, J., \& Laiho, R. (2007). Effects of short- and long-term water-level drawdown on the populations and activity of aerobic decomposers in a boreal peatland. Global Change Biology, 13, 491-510.

Jaffrain, J., Gérard, F., Meyer, M., \& Ranger, J. (2007). Assessing the Quality of Dissolved Organic Matter in Forest Soils Using Ultraviolet Absorption Spectrophotometry. Soil Science Society of America Journal, 71, 1851-1858.

Jassey, V.E.J., Chiapusio, G., Gilbert, D., Toussaint, M-L., \& Binet, P. (2012). Soil Biology \& Biochemistry. Soil Biology and Biochemistry, 46, 49-52.

Jassey, V.E.J., Lamentowicz, M., Bragazza, L., Hofsommer, M. L., Mills, R.T.E., ... \& Robroek, B.J.M. (2016). Loss of testate amoeba functional diversity with increasing frost intensity across a continental gradient reduces microbial activity in peatlands. European Journal of Protistology, 55, 190-202.

Kaisermann, A., Maron, P.A., Beaumelle, L., \& Lata, J.C. (2015). Fungal communities are more sensitive indicators to non-extreme soil moisture variations than bacterial communities. Applied Soil Ecology, 86, 158-164.

Kaisermann, A., de Vries, F.T., Griffiths, R.I., \& Bardgett, R.D. (2017). Legacy effects of drought on plant-soil feedbacks and plant-plant interactions. The New phytologist, 215, 1413-1424.

Abarenkov, K., Tedersoo, L., Nilsson. H. R., Vellak, K, Saar, I., Veldre, V., ... \& Köljalg, U. (2010). PlutoF-a Web Based Workbench for Ecological and Taxonomic Research, with an Online Implementation for Fungal ITS Sequences. Evolutionary Bioinformatics, 2010, 189-8.

Kõljalg, U., Nilsson, R.H., Abarenkov, K., Tedersoo, L, Taylor, A.F.S., Bahram, M., ... \& Larsson, K-H. (2013). Towards a unified paradigm for sequence-based identification of fungi. Molecular Ecology, 22, 5271-5277.

Kreyling, J., Jentsch, A., \& Beier, C. (2014). Beyond realism in climate change experiments: gradient approaches identify thresholds and tipping points. Ecology Letters, 17, 125-126.

Kuiper, J.J., Mooij, W.M., Bragazza, L., \& Robroek, B.J.M. (2014). Plant functional types define magnitude of drought response in peatland CO2 exchange. Ecology, 95, 123-131.

Lamentowicz, M., Slowinska, S., Slowinski, M., Jassey, V.E.J., Chojnicki, B.H., Reczuga, M. K., ... \& Buttler, A. (2016). Combining short-term manipulative experiments with long-term palaeoecological investigations at high resolution to assess the response of. Mires and Peat, 18, 1-17.

Lesica, P., \& Crone, E.E. (2017). Arctic and boreal plant species decline at their southern range limits in the Rocky Mountains. Ecology Letters, 20, 166-174.

This article is protected by copyright. All rights reserved. 
Loreau, M. (2001). Biodiversity and Ecosystem Functioning: Current Knowledge and Future Challenges. Science, 294, 804-808.

Lu, X., Gray, C., Brown, L.E., Ledger, M.E., Milner, A.M., ... \& Ma, A. (2016). Drought rewires the cores of food webs. Nature Climate Change, 6, 875-878.

Maestre, F.T., Quero, J.L., Gotelli, N.J., Escudero, A., Ochoa, V., Delgado-Baquerizo, M., ... \& Zaady, E. (2012). Plant species richness and ecosystem multifunctionality in global drylands. Science, 335, 214-218.

Mahé, F., Rognes, T., Quince, C., de Vargas, C., \& Dunthorn, M. (2014). Swarm: robust and fast clustering method for amplicon-based studies. PeerJ, 2, e593.

Muggeo, V. (2008). Segmented: an R package to fit regression models with broken-line relationships. $R$ news, 14, 293-313.

Nguyen, N.H., Song, Z., Bates, S.T., Branco, S., \& Tedersoo, L. (2016). FUNGuild: an open annotation tool for parsing fungal community datasets by ecological guild. Fungal Ecology, $20,241-248$.

Pinheiro, J.C., \& Bates, D.M. (2000). Mixed-effects models in S and S-PLUS. Statistics and Computing. Springer-Verlag.

R Core Team. (2015). R: A language and environment for statistical computing. R Foundation for Statistical Computing, Vienna, Austria.

Robroek, B.J.M., Albrecht, R., Hamard, S., Pulgarin, A., Bragazza, L., Buttler, A., \& Jassey, V.E.J. (2016). Peatland vascular plant functional types affect dissolved organic matter chemistry. Plant and Soil, 407, 135-143.

Robroek, B.J.M., Jassey, V.E.J., Kox, M.A.R., Berendsen, R.L., Mills, R.T.E, Cécillon, L., ... \& Bodelier, P.L.E. (2015). Peatland vascular plant functional types affect methane dynamics by altering microbial community structure. Journal of Ecology, 103, 925-934.

Rousk, J., Smith, A.R., \& Jones, D.L. (2013). Investigating the long-term legacy of drought and warming on the soil microbial community across five European shrubland ecosystems. Global Change Biology, 19, 3872-3884.

Scheffer, M., \& Carpenter, S.R. (2003). Catastrophic regime shifts in ecosystems: linking theory to observation. Trends in Ecology \& Evolution, 18, 648-656.

Scheffer, M., Carpenter, S.R., Lenton, T.M., Bascompte, J., Brock, W., Dakos, V., de Koppel, J., ... \& Vandermeer, J. (2012). Anticipating critical transitions. Science, 338, 344-348.

Sistla, S.A., Moore, J.C., Simpson, R.T., Gough, L., Shaver, G.R., Schimel, J.P. (2014). Long-term warming restructures Arctic tundra without changing net soil carbon storage. Nature, 497, 615-618.

Steinauer, K., Chatzinotas, A., \& Eisenhauer, N. (2016). Root exudate cocktails: the link between plant diversity and soil microorganisms? Ecology and Evolution, 6, 7387-7396.

This article is protected by copyright. All rights reserved. 
Suding, K.N., \& Hobbs, R.J. (2009). Threshold models in restoration and conservation: a developing framework. Trends in Ecology \& Evolution, 24, 271-279.

Tedersoo, L., Bahram, M., Põlme, S., Kõljalg, U., Yorou, N.S., Wijesundera, R., Ruiz, L.V., ... \& Abarenkov, K. (2014). Fungal biogeography. Global diversity and geography of soil fungi. Science, 346, 1256688-1256688.

Tilman, D., Isbell, F., \& Cowles, J.M. (2014). Biodiversity and Ecosystem Functioning. dx.doi.org, $45,471-493$.

van de Pol, M., Jenouvrier, S., Cornelissen, J.H.C., \& Visser, M.E. (2017). Behavioural, ecological and evolutionary responses to extreme climatic events: challenges and directions. Philosophical Transactions of the Royal Society of London B: Biological Sciences, 372, 20160134-16.

van der Putten, W.H., Bardgett, R.D., Bever, J.D., Bezemer, T.M., Casper, B.B., Fukami, T., ... \& Wardle, D.A. (2013). Plant-soil feedbacks: the past, the present and future challenges. Journal of Ecology, 101, 265-276.

Vanacker, M., Wezel, A., Payet, V., \& Robin, J. (2015) Determining tipping points in aquatic ecosystems: The case of biodiversity and chlorophyll $\alpha$ relations in fish pond systems. Ecological indicators, 52, 184-193.

Walker, M.D., Wahren, C.H., Hollister, R.D., Henry, G.H., Ahlquist, L.E., Alatalo, J.M., ... \& Wookey, P.A. (2006). Plant community responses to experimental warming across the tundra biome. Proceedings of the National Academy of Sciences of the United States of America, 103,13421346.

Walker, T.N., Garnett, M.H., Ward, S.E., Oakley, S., Bardgett, R.D., \& Ostle, N.J. (2016). Vascular plants promote ancient peatland carbon loss with climate warming. Global Change Biology, $22,1880-1889$.

Walker, T.N., Ward, S.E., Ostle, N.J., \& Bardgett, R.D. (2015). Contrasting growth responses of dominant peatland plants to warming and vegetation composition. Oecologia, 178, 141151.

Wang, H., Richardson, C.J., \& Ho, M. (2015). Dual controls on carbon loss during drought in peatlands. Nature Climate Change, 5, 584-587.

Ward, S.E., Orwin, K.H., Ostle, N.J., Briones, M.J.I., Thomson, B.C., Griffiths, R.I., ... \& Bardgett, R.D. (2015). Vegetation exerts a greater control on litter decomposition than climate warming in peatlands. Ecology, 96, 113-123.

Ward, S.E., Ostle, N.J., Oakley, S., Quirk, H., Henrys, P.A., \& Bardgett, R.D. (2013). Warming effects on greenhouse gas fluxes in peatlands are modulated by vegetation composition. Ecology Letters, 16, 1285-1293.

Wellstein, C., Poschlod, P., Gohlke, A., Chelli, S., Campetella, G., Rosbakh, S., ... \& Beierkuhnlein, C. (2017). Effects of extreme drought on specific leaf area of grassland species: A metaanalysis of experimental studies in temperate and sub-Mediterranean systems. Global Change Biology, 23, 2473-2481.

This article is protected by copyright. All rights reserved. 
Werth, M., \& Kuzyakov, Y. (2008). Root-derived carbon in soil respiration and microbial biomass determined by 14C and 13C. Soil Biology and Biochemistry, 40, 625-637.

Yletyinen, J., Bodin, Ö., Weigel, B., Nordström, M.C., Bonsdorff, E., \& Blenckner, T. (2016). Regime shifts in marine communities: a complex systems perspective on food web dynamics. Proceedings of the Royal Society B: Biological Sciences, 283, 20152569.

Yu, Z., Beilman, D.W., Frolking, S., MacDonald, G.M., Roulet, N.T., Camill, P., \& Charman, D.J. (2011). Peatlands and Their Role in the Global Carbon Cycle. Eos, 92, 97-108.

Yuste, J.C., Peñuelas, J., Estiarte, M., Garci-Mas, J., Mattana, S., ... \& Sardans, J. (2011).

Drought-resistant fungi control soil organic matter decomposition and its response to temperature. Global Change Biology, 17, 1475-1486.

Zhao, M., \& Running, S.W. (2010). Drought-induced reduction in global terrestrial net primary production from 2000 through 2009. Science, 329, 940-943.

Table

Table 1: Components of hypotheses represented by the structural equation model

\begin{tabular}{|c|c|}
\hline Path & Causal hypothesis \\
\hline wtd1-5 & $\begin{array}{l}\text { Decreasing water level directly promotes ecosystem respiration (wtd1). Drop in water } \\
\text { table directly shifts WEOM quality (wtd2) and/or promotes enzyme activities due to } \\
\text { higher oxygen availability (wtd3; Fenner \& Freeman, 2011). Lower water level influences } \\
\text { the fungal community composition through effects in fungal diversity and fungal richness } \\
\text { (wtd4; Jaatinen et al., 2007). Vascular plants (graminoids and ericoids) respond } \\
\text { positively to decreasing water level while Sphagnum responds negatively (wtd5). }\end{array}$ \\
\hline vp1 & $\begin{array}{l}\text { Changes in vegetation community composition influences fungal community } \\
\text { composition. For instance, an increase of ericoids may favour ericoid mycorrhizal fungi. }\end{array}$ \\
\hline vp2 & $\begin{array}{l}\text { Vegetation directly influences ecosystem } \mathrm{CO}_{2} \text { respiration through autotrophic } \\
\text { respiration. }\end{array}$ \\
\hline vp3 & $\begin{array}{l}\text { An increase of vascular plants promotes microbial enzyme activities, likely through root- } \\
\text { exudates (Dieleman et al., 2017). }\end{array}$ \\
\hline vp4 & $\begin{array}{l}\text { Shifts in plant community composition influence the quantity and/or quality of the water } \\
\text { extractable organic matter (WEOM) through the release of organic compounds (Robroek } \\
\text { et al., 2016). }\end{array}$ \\
\hline fun1 & Fungi directly influences ecosystem $\mathrm{CO}_{2}$ respiration through heterotrophic respiration. \\
\hline fun2 & $\begin{array}{l}\text { Fungal community composition influences microbial enzyme activities. For example, an } \\
\text { increase of saprotrophs may promote enzyme activities. }\end{array}$ \\
\hline weom1 & Shifts in the quantity and/or quality of WEOM influence fungal community composition. \\
\hline
\end{tabular}

This article is protected by copyright. All rights reserved. 


\begin{tabular}{l|l}
\hline weom2 & $\begin{array}{l}\text { Shifts in the quantity and/or quality of WEOM influence enzyme activities. For instance, } \\
\text { an increase of simple organic compounds will promote hydrolase activities while an } \\
\text { increase of recalcitrant compounds such as polyphenols will increase oxidases (Robroek } \\
\text { et al., 2016). }\end{array}$ \\
\hline enz1 & $\begin{array}{l}\text { Increasing microbial enzymatic activities promote ecosystem } \mathrm{CO}_{2} \text { respiration; the more } \\
\text { active microbes are, the more they respire (Fenner \& Freeman, 2011). }\end{array}$ \\
\hline
\end{tabular}

\section{Figure captions}

Figure 1: A priori conceptual structural equation model (SEM) depicting pathways by which water table depth, dissolved organic matter (WEOM), vegetation, fungi and enzymes may influence ecosystem $\mathrm{CO}_{2}$ respiration (see Table 1 for detailed hypotheses). For simplicity, we only show global pathways by variable category (e.g. fungi); a detailed version of the model is given in Fig. S1. Letters correspond to hypothetical pathways (Table 1). Fundiv = fungal diversity; Funrich = fungal richness; Funcomp = fungal community composition (NMDS axis 1); gram $=$ graminoid cover $;$ eric $=$ ericoid cover; b.nana $=$ Betula nana cover $;$ sph $=$ Sphagnum cover; weoc $=$ water extractable organic carbon; weon $=$ water extractable organic nitrogen; Spectral slope $=$ spectral slope of the WEOM; pox = phenoloxidases $($ POX + PEROX $) ;$ hydro $=$ hydrolases (PCA axis 1 run on BX, AG, BG, CHI, LAP, ArAP, AAP, AP). Hydrolases abbreviations can be find in Table S4.

Figure 2: Response of the water table depth (WTD) to manipulation in 2013 and 2014. (a) Effect of water level manipulation over time on water level depth. Vertical lines represent the sampling dates. (b) Decomposition of the water level depth time series into its trend and seasonal figures (see method). Trends are different in 2013 and 2014 while the seasonal figure remain similar between 2013 and 2014. Red lines represent the different sampling dates.

This article is protected by copyright. All rights reserved. 
Figure 3: Response of vascular plants and Sphagnum mosses to water level manipulations and water level gradient. (a) Effect of water level manipulation on total vascular plant and Sphagnum covers at each sampling date (detailed statistics can be found in Table S4). Letters indicate significant differences among water level treatments at a specific period. (b) Response of total vascular plant cover to water level gradient. Slope coefficients from each side of the tipping point are shown on the left. AT $=$ Above threshold; $\mathrm{BT}=$ Below threshold. Dots colours indicate the total graminoid cover. Confidence interval of the threshold is shown in grey.

Figure 4: Response of dissolved organic matter quality to water level manipulations and water level gradient. (a) Effect of water level manipulation on water extractable organic matter (WEOM) quality (spectral slope $S_{250-465}$ ) at each sampling period (detailed statistics can be found in Table S4). Letters indicate significant differences among water level treatments at a specific period. (b) Response of WEOM quality (spectral slope coefficient, $S_{250-465}$ ) to water level gradient. Slope coefficients from each side of the tipping point are shown on the left. AT $=$ Above threshold; BT $=$ Below threshold. Dots colours indicate the total graminoid cover as in Fig. 3. Confidence interval of the threshold is shown in grey.

Figure 5: Response of belowground components to water level gradient. (a) Fungal species change points along the water level gradient (purity $>99 \%, P<0.05$ in $>99 \%$ bootstraps) showing $5 \%$ and $95 \%$ bootstrap percentiles; dot colours reflect the function of the species. Only species that reduced in abundance with wet conditions are shown. Critical changing area reflects the $5-95 \%$ bootstrap percentile range (in grey) of community change point (see subset c). All details about OTUs are given in table S2. (b) Sum of z scores (z-) over all the gradient according to fungal functions. (c) Community change point for OTUs reduced in abundance along with wet conditions showing community threshold (dotted line) at $\max \left(\left[\operatorname{sum}\left(\mathrm{z}^{-}\right)\right]\right)$and 5-

This article is protected by copyright. All rights reserved. 
95\% bootstrap percentile range. [sum(z-)] values represent the sum of responses for each possible change point along the gradient. (d-e) Enzyme multifunctionality and ecosystem $\mathrm{CO}_{2}$ respiration as a function of water level depth. Slope coefficients from each side of the tipping point are shown on the right. AT $=$ Above threshold; $\mathrm{BT}=$ Below threshold. Confidence intervals of the thresholds are shown in grey.

\section{Figure 6: Moving window Structural Equation Modelling (SEM) evaluating the drivers of} ecosystem $\mathrm{CO}_{2}$ respiration. (a) Biplot showing the relationship between the response of ecosystem $\mathrm{CO}_{2}$ respiration ( $R^{2}$-adjusted) by plant-fungal interactions in each SEM produced along the water level gradient (moving window SEM). Open symbols are SEMs with an unsatisfactory fit, filled symbols show the opposite. See Fig. S1 for the full a priori model considered. (b) Averaged moving window SEMs reflecting the main drivers of ecosystem $\mathrm{CO}_{2}$ respiration for each of the three phases illustrated in (a). WTD = water level depth; Gram = graminoid cover; $\mathrm{WEOM}=$ quality of $\mathrm{WEOM}$ (spectral slope); Fun = fungal community composition; $\mathrm{Enz}=$ enzyme multifunctionality; $\mathrm{R}_{\mathrm{ECO}}=$ ecosystem $\mathrm{CO}_{2}$ respiration. Grey lines indicate non-significant paths. Only standardized path coefficients with $P<0.05$ are shown. The amount of variance explained $\left(R^{2}\right.$, in italics) for each response variable are given on their respective box. All details of moving window SEM are given in Table S6, including model fits. Note: the SEMs presented here were computed on the data set from 2013 only as fungi were not quantified in 2014. We, however, run a similar model but without fungi through the entire data set and found similar outputs (see Fig. S9). (c) Ecosystem $\mathrm{CO}_{2}$ respiration plotted against the averaged response intensity (standardized effect sizes) of its drivers. Dot colours represent the variation of water level from the tipping point $-24 \mathrm{~cm}$ highlighted in moving window SEMs.

This article is protected by copyright. All rights reserved. 


\section{Supplementary tables}

Table S1: Summary of linear effect mixed models testing the cutting effect (fixed effect) over time (linear mixed effect models)

Table S2: Assignation of fungal OTUs and the associated functions. Change points of fungi along the water level gradient (TITAN analysis)

Table S3: Details of the different enzyme activities quantified in this study

Table S4: Summary of linear mixed effects models. Abbreviations for enzymes are given in Table S3. $\mathrm{R}_{\mathrm{eco}}=$ ecosysem CO2 respiration.

Table S5: Summary of breaking point analyses on enzymes, plants, WEOM quality and ecosystem respiration. Abbreviations for enzymes are given in Table S3. ${ }^{*}, P<0.05$; ${ }^{* *}, P<0.01$; ***, $P<0.001$

Table S6: Summarised output from moving window structural equation modelling. Estimates in bold are significant at $\mathrm{P}<0.05$. Path labels refer to Figure $\mathrm{S} 1$.

\section{Supplementary figures}

Figure S1: A priori structural equation model. (a) Pathway diagram showing all the hypothetical relationships considered in the full a priori model (Fig. 1). (b) Structural equation model based on the a priori model $\left(\mathrm{X}^{2}=22.8, \mathrm{df}=18, \mathrm{P}=0.20, \mathrm{GFI}=0.95, \mathrm{RMSE}=0.07, \mathrm{SRMR}=0.02, \mathrm{AIC}=\right.$ 258.8). Green arrows represent positive interactions; red arrows represent negative interactions. Colour intensity and width of the arrows is based on their standardized estimates weight. Single-headed arrows represent direct relationships between two variables; Doubleheaded arrows between two variables indicate possible interactions among error terms of the variable considered. fundiv $=$ fungal diversity; funrich $=$ fungal richness; funcomp $=$ fungal

This article is protected by copyright. All rights reserved. 
community composition (NMDS axis 1); veg = vegetation community composition (NMDS axis 1); gram = graminoid cover; eric = ericoid cover; b.nana = Betula nana cover; sph = Sphagnum cover; weoc $=$ water extractable organic carbon; weon = water extractable organic nitrogen; $\mathrm{S}_{250-465}=$ spectral slope of the WEOM; $\mathrm{M}_{\mathrm{enz}}=$ enzyme multifunctionality (PCA axis 1$)$; pox = oxidases; hydro = hydrolases.

Figure S2: Temporal variations of air and peat temperatures, vapour pressure deficit (VPD) and precipitation in 2013 and 2014. As no significant difference was found between Wet, Ambient and Dry treatments, only data from Ambient plots were shown.

Figure S3: (a-b) Effect of water level treatment on dominant ericoid (Oxycoccus palustris) and graminoid (Eriophorum vaginatum) species in the plant community at each sampling date. (c-d) Effect of water level manipulation on water extractable organic carbon (WEOC) and nitrogen (WEON), as well as on Specific Ultraviolet Absorbance at $254 \mathrm{~nm}\left(\mathrm{SUVA}_{254}\right)$ at each sampling period (detailed statistics are given in Table S4). Letters indicate significant differences among water level treatments at a specific period $(P<0.05$, linear mixed effects models). When no significant difference was found overall, no letter was added.

Figure S4: Effect of water level treatment on fungal OTU richness at each sampling period. Letters indicate significant differences among water level treatments at a specific period $(P<$ 0.05 , linear mixed effects models).

Figure S5: Effects of water table depth and water level treatment on (a) fungal community composition (Non-metric multidimensional scaling analysis, NMDS; stress level $=0.02$ ) and (b) enzyme activities (Principal component analysis, PCA). Values represent means of sites scores from the same treatment and date \pm SE. Tests on axes have been done using site scores as response variable in a linear mixed effect model with trend in water table depth, water table treatment and seasonality as explanatory variables (see method).

This article is protected by copyright. All rights reserved. 
Figure S6: Effects of water level treatment on each enzyme activities at each sampling period. Detailed statistics are given in Table S3. Letters indicate significant differences among water level treatments at a specific period $(P<0.05$, linear mixed effects models).

Figure S7: Hydrolytic and oxidative enzyme activities (log-transformed) as a function of water level depth. Slope coefficients from each side of the tipping point are given on the top oach graph. Confidence intervals of the thresholds are shown in grey. Abbreviations for enzymes are given in Table S3.

Figure S8: Effects of water level treatment on ecosystem $\mathrm{CO}_{2}$ respiration at each sampling period. Detailed statistics are given in Table S4.

Figure S9: Biplot showing the relationship between the response of ecosystem $\mathrm{CO}_{2}$ respiration ( $\mathrm{R}^{2}$-adjusted) by plant-soil interactions in each SEM produced along the water level gradient (moving window SEM) using the entire data set but without fungi.

Figure S10: Structural Equation Model (SEM) testing the biogeochemical cascade driven by oxygen in peatlands (Fenner \& Freeman, 2011). WTD = water level depth; Gram = graminoid cover; WEOM = quality of WEOM (spectral slope); Fun = fungal community composition (NMDS axis 1); Hydro = hydrolytic enzymes (PCA axis 1); POX = oxidases (peroxidases + phenoloxidases); $\mathrm{R}_{\mathrm{ECO}}=$ ecosystem $\mathrm{CO}_{2}$ respiration. Grey lines indicate non-significant paths. Only standardized path coefficients with $P<0.05$ are shown. The amount of variance explained $\left(R^{2}\right.$, in italics) for each response variable are given on their respective box. Model fit is poor: $\mathrm{X}^{2}=$ 20.6, $\mathrm{Df}=10, \mathrm{P}=0.02, \mathrm{CFI}=0.91, \mathrm{RMSEA}=0.18, \mathrm{SRMR}=0.10$. The model shows that oxidases do not play a significant role in increasing ecosystem CO2 respiration via the biogeochemical cascade. In addition, it underlined again the role of graminoids in driving ecosystem $\mathrm{CO}_{2}$ respiration through its effect on DOM aromaticity.

Figure S11: Water table depth fluctuations since 2013 up to June 2017 in control plots (un-cut plots).

This article is protected by copyright. All rights reserved. 


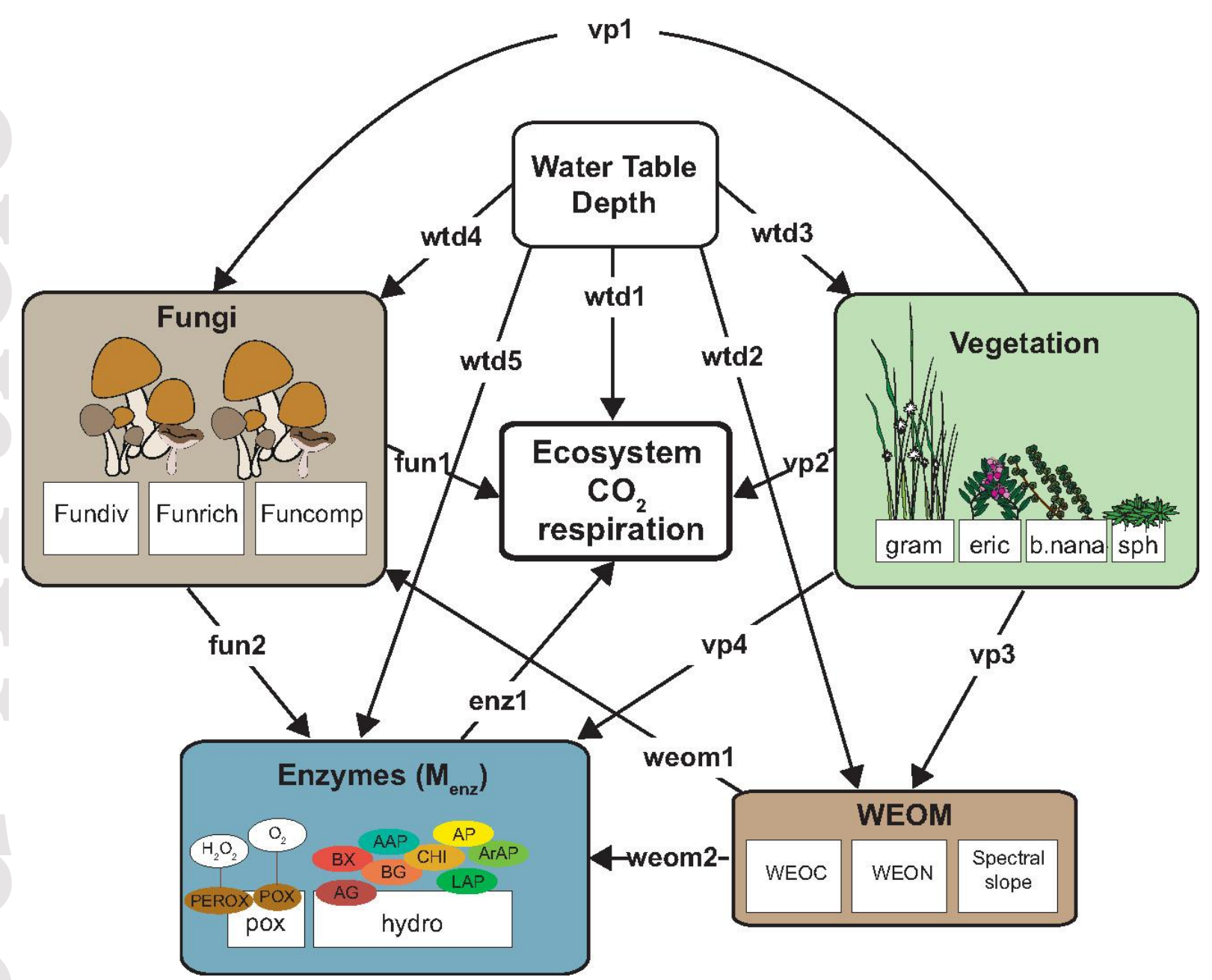

(a)

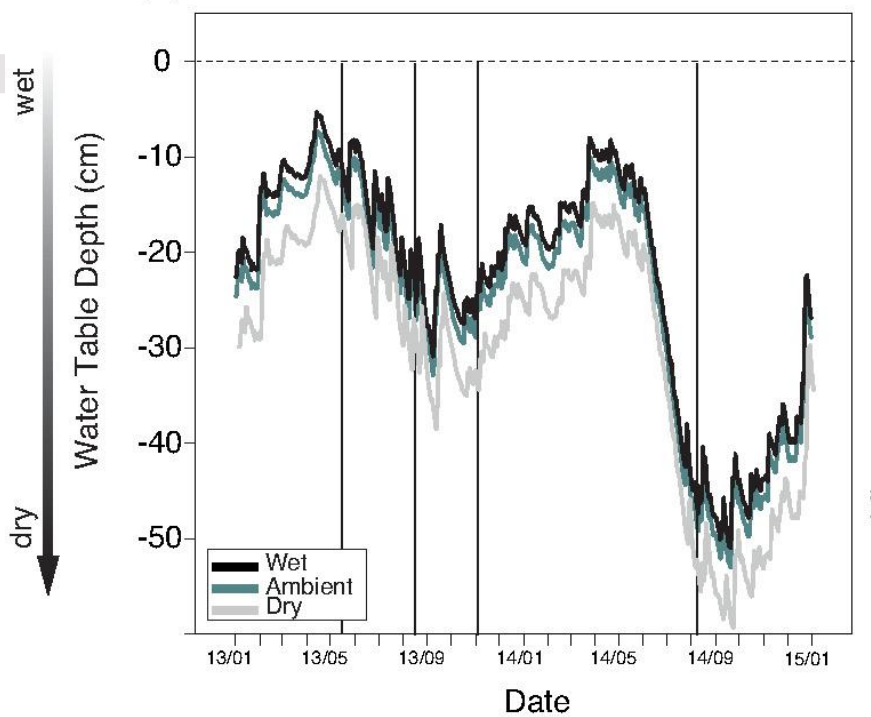

(b)

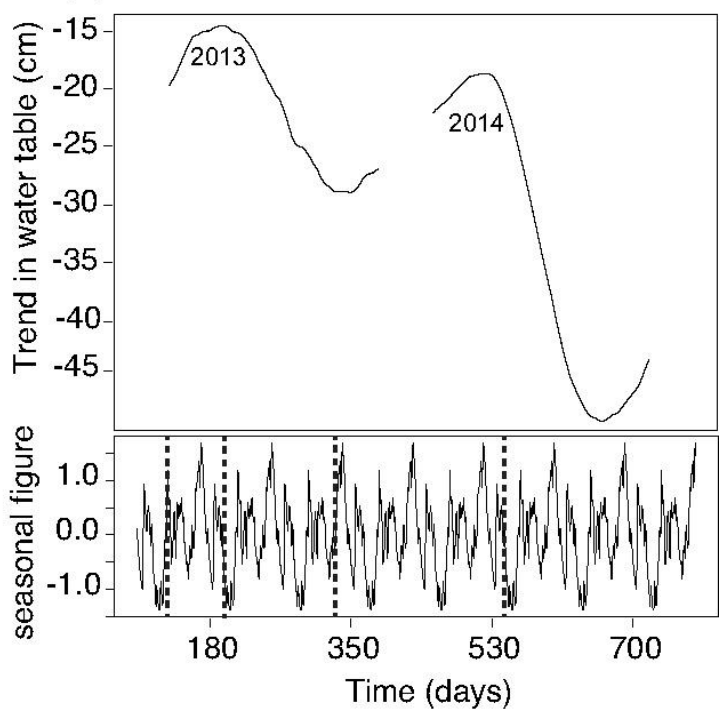

This article is protected by copyright. All rights reserved. 

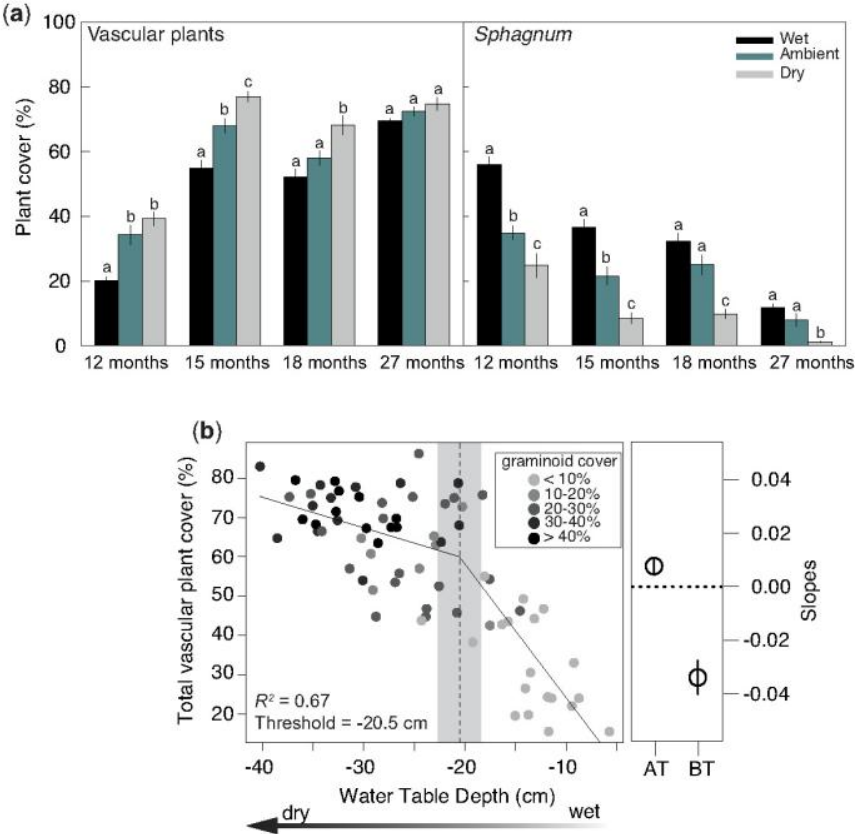

\section{(a)}

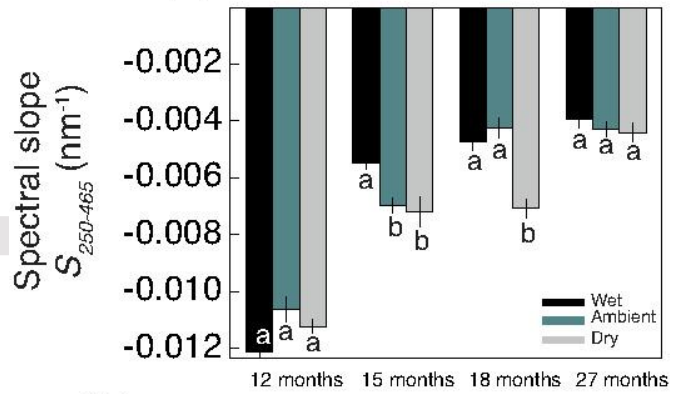

(b)

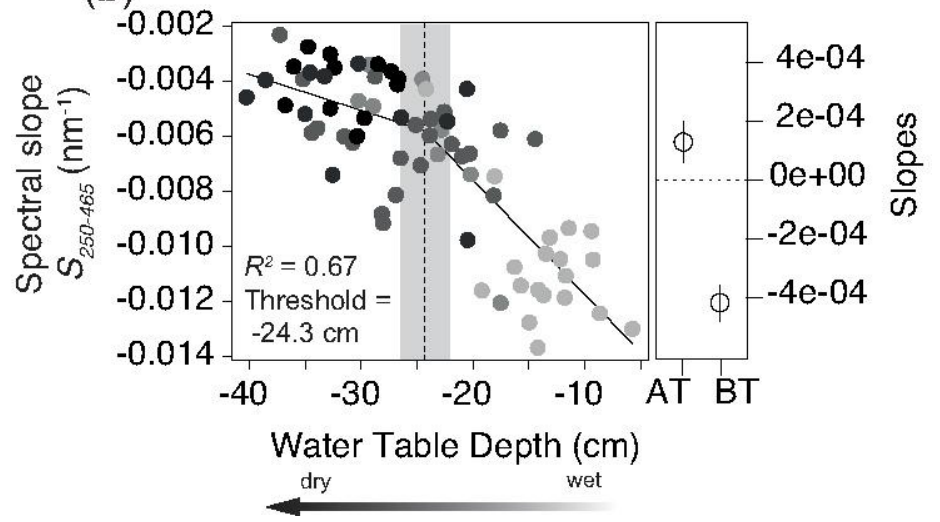

This article is protected by copyright. All rights reserved. 
(a)

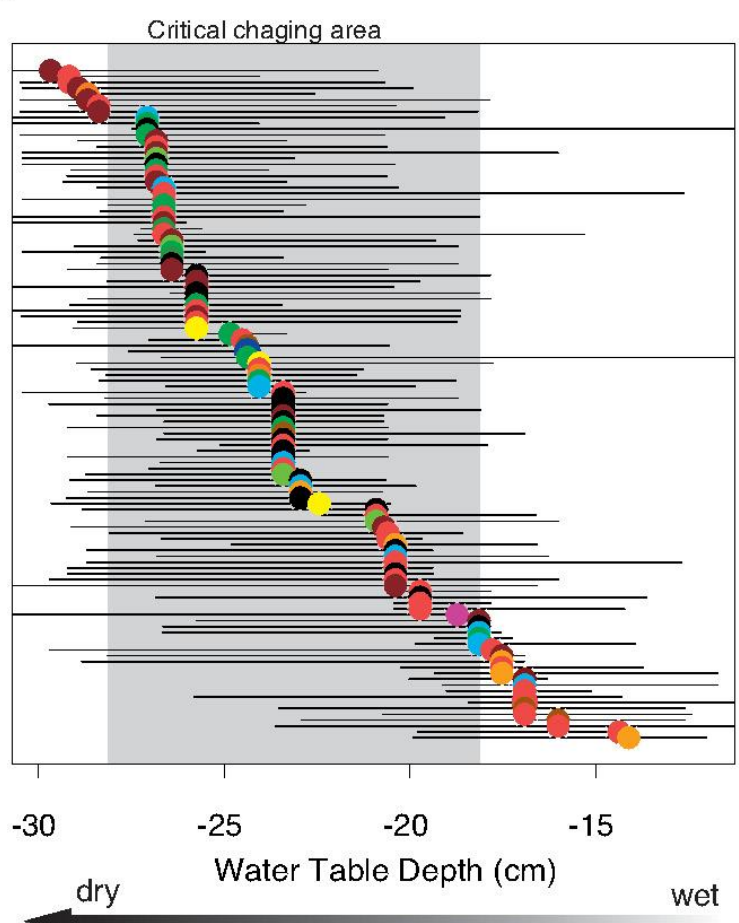

(d)

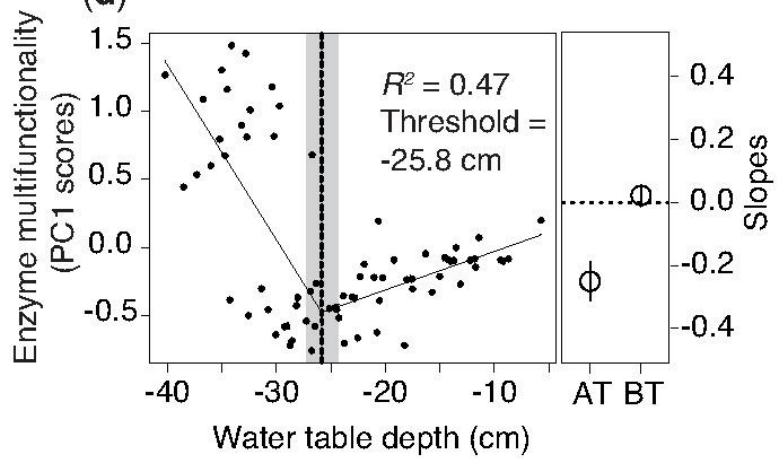

(b)

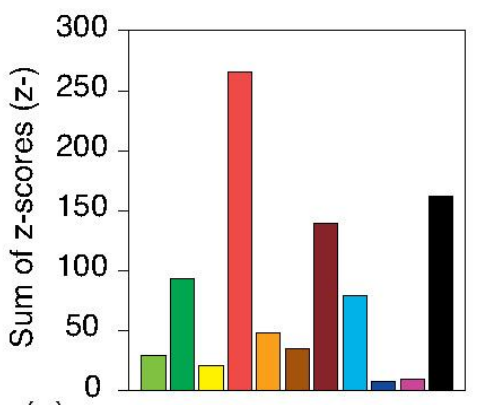

(c)

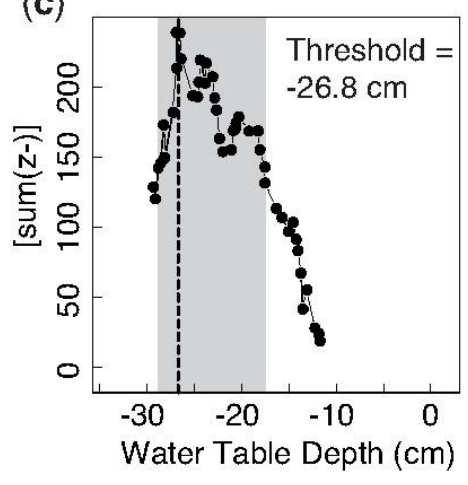

Symbiotrophs

Undefined root endophyte

Ectomycorrhizal fungi

Lichenized fungi

Pathotrophs

Plant pathogen

Animal pathogen

Mycoparasite

Saprotrophs

Undefined saprotroph

Leafflitter saprotroph

Wood saprotroph

Undefined saprotroph /

ecotomycorrhizal fungi

Unkown (e)

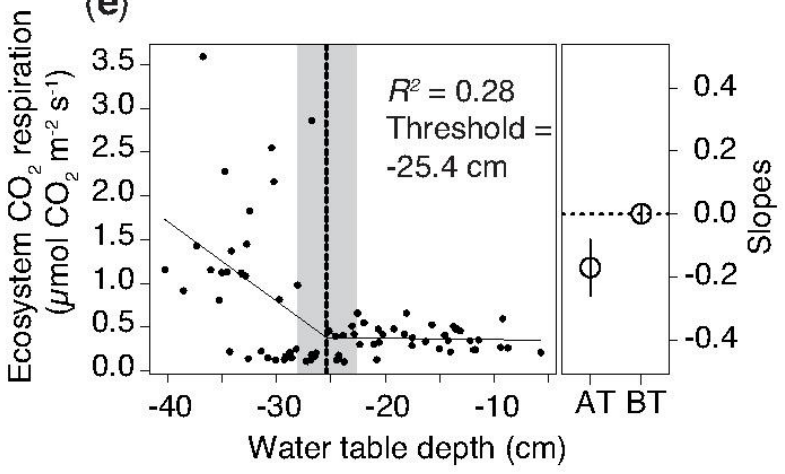

This article is protected by copyright. All rights reserved. 


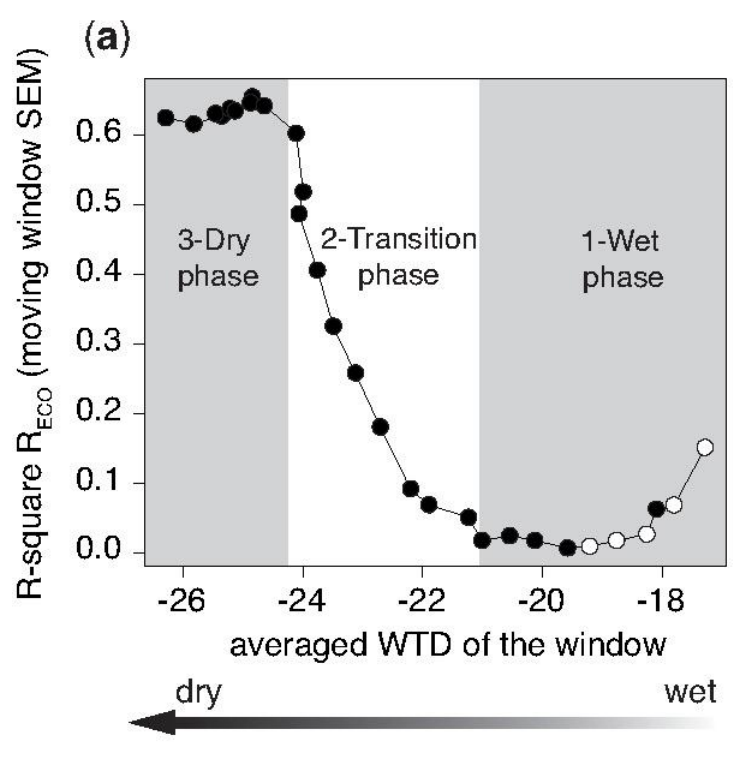

(b)

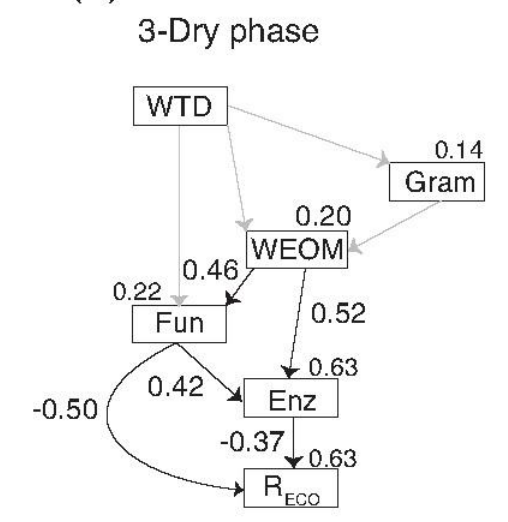

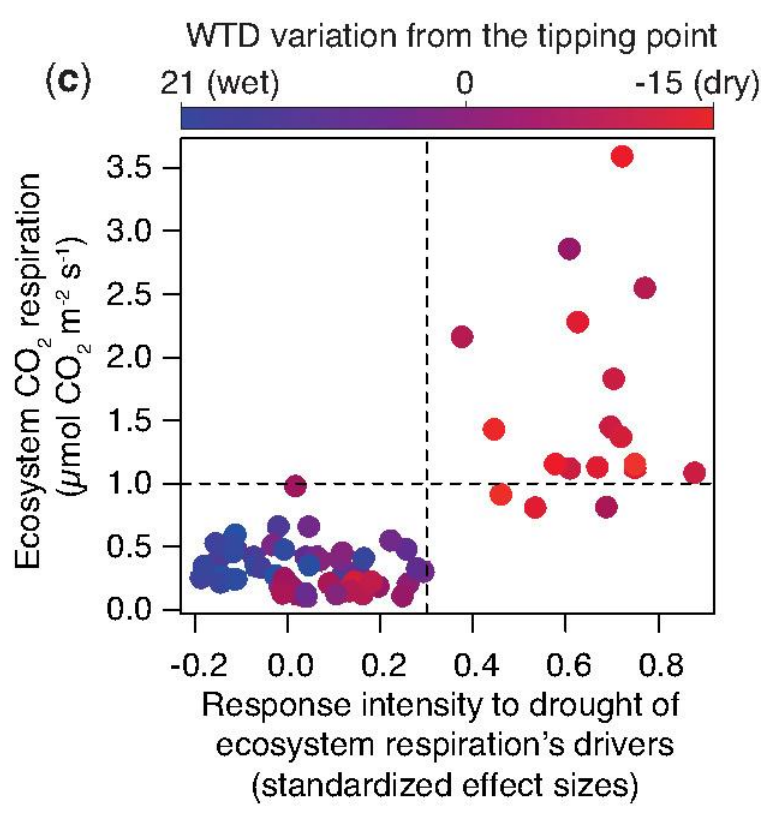

2-Transition phase

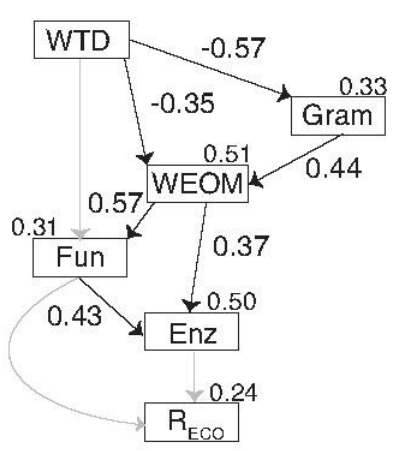

1-Wet phase

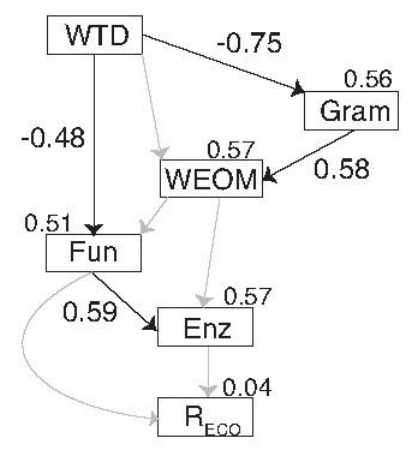

This article is protected by copyright. All rights reserved. 